\title{
Measurement of dietary nutrient intake in free-ranging mammalian herbivores
}

\author{
Robert W. Mayes ${ }^{1 *}$ and Hugh Dove ${ }^{2}$ \\ ${ }^{1}$ Macaulay Land Use Research Institute, Craigiebuckler, Aberdeen AB15 8QH, Scotland, UK \\ ${ }^{2}$ CSIRO Plant Industry, GPO Box 1600, Canberra, ACT 2601, Australia
}

\begin{abstract}
The nutrient intakes of mammalian herbivores depend on the amount and the nutrient content of the plant species and plant parts which they eat. We review the merits of oesophageal-fistulated (OF) animals, microhistological procedures, stable C-isotope discrimination and plant cuticular-wax markers as methods for estimating diet composition and intake in both ruminant and non-ruminant herbivores. We also briefly discuss methods based on grazing behaviour measurements or on $\mathrm{H}_{2} \mathrm{O}$ or $\mathrm{Na}$ turnover, and methods for estimating supplement or soil intake. Estimates of intake in ruminants are often based on separate measurements of faecal output and herbage digestibility. We review this approach and emphasize that, under some circumstances, the applicability of in vitro digestibility estimates based on OF extrusa is questionable. We discuss how plant-wax marker patterns can be used to check whether OF and test animals are consuming similar diets, but also emphasize that a major advantage of the use of plant-wax markers is that this approach may obviate altogether the need for OF animals. Estimates of total herbage intake can be partitioned into the intakes coming from different plant species and/or parts, provided diet composition can be measured. Diet composition estimates based on C-isotope discrimination have the major disadvantage that they cannot be taken to species level. By contrast, microhistological methods can identify many plant species in extrusa, digesta or faeces, but often a large proportion of plant fragments remains unidentifiable. Plant-wax hydrocarbons show great promise as markers for estimating diet composition and intake. However, we suggest that to be applicable in complex plant communities there is a need with this method either to recruit a wider range of wax markers (e.g. alcohols, sterols, fatty acids) or to use it in combination with other methods. We suggest that, in turn, this generates an urgent need for research on statistical aspects of the combined use of markers or methods, in relation to the error structures of the data or methods being combined and the standard errors of the resultant estimates of diet composition and intake. We conclude by discussing the extension of intake and/or diet
\end{abstract}

\footnotetext{
Abbreviation: OM, organic matter.

*Corresponding author: Dr Robert Mayes, fax + 44 (0) 1224 311556, email r.mayes@mluri.sari.ac.uk
} 
composition measurements to the measurement of nutrient transactions within the gut, particularly in relation to the supply of absorbable nutrients.

\section{Herbivores: Nutrient intake}

\section{Introduction}

Free-ranging domestic or wild herbivores exert choice in consuming the various parts of plants and species from the available vegetation. Since the concentrations of nutrients can vary considerably among the different dietary plant parts and species selected, this choice can markedly affect the herbivore's nutirent intake (Dove et al. 1999). Despite this, most quantitative studies of nutrient intake and utilization, especially with domestic livestock, have used housed captive animals, often fed on diets bearing little resemblance to those likely to be selected by grazing animals. Nutrient intake is the major determinant of nutritional status and production performance in farm livestock. Consequently, there have been numerous estimates of herbage intake by grazing ruminants, but few intake measurements in free-ranging pigs and horses. For all free-ranging domestic livestock, the number of diet composition estimations has been relatively small. In contrast, dietary studies with free-living wild herbivores have largely been confined to estimates of diet composition (Cornelis et al. 1999).

Mammalian herbivores, whether wild or domesticated, are significant components of natural or agricultural ecosystems. Not only will the wellbeing of a herbivore population be influenced by the nutritional status of its component individuals, but the type and quantity of the plant material they consume may affect the distribution patterns and numbers of plant and other animal species within the ecosystem. Hence, an understanding of the quantitative interaction between herbivores and plants is central to ensuring the long-term sustainability of these ecosystems. Furthermore, herbivores will influence the dynamic distribution of minerals and other nutrients within the ecosystem, through ingestion of plant material and redistribution by the deposition of excreta (for example see Pastor et al. 1993). The distribution of persistent pollutants in the environment, such as radionuclides and heavy metals, will similarly be affected (for example see Salt et al. 1992). The fact that the major factors influencing intake in free-ranging herbivores may differ greatly from those in housed animals emphasizes the need to measure intake, both of the complete diet and of its individual components, in grazing and browsing animals.

This present review is concerned with the assessment of what herbivores eat and their resultant intake of nutrients. We will not enter the current debate about why a herbivore selects a particular diet, or why it chooses to start or to finish eating (Day et al. 1998; Provenza et al. 1998). Nevertheless, many of the techniques discussed in this review are now sufficiently well developed that they can help to answer these questions. Similarly, most of the concepts may equally apply to the estimation of the intake of other substances in the diet, such as plant secondary compounds and environmental pollutants. Furthermore, some of the techniques for determining intake require prior knowledge of dietary composition. Intake of specific nutrients or other substances (for example see Mayes et al. 1994; Dove et al. 1999) can be determined from estimates of the intake of DM or organic matter (OM), and concentrations of the substance under investigation. Additional techniques may be required to estimate the digestible (or absorbable) intake of a nutrient or supply of a fermentation product such as microbial protein.

Determinations of intake and diet composition in free-ranging herbivores are generally difficult to undertake, and their errors are often large, mainly owing to the limitations of available measurement techniques. The measurement processes themselves may disturb the 
animals to the extent that their normal foraging behaviour may be compromised; this can be a major problem in rangeland, forest and other semi-natural environments. Furthermore, there is no true means of evaluating these techniques under free-ranging conditions, except by comparison with alternative, possibly inferior, methods. The indoor testing of such techniques, by feeding known quantities of vegetation of defined composition, generally provides an acceptable, but not absolute, validation.

Techniques for intake estimation have been extensively reviewed (for example see Langlands, 1987; Dove \& Mayes, 1991). Most were developed for use in ruminant livestock, grazing simple grass swards which could be considered atypical compared with the conditions experienced by most of the world's large herbivores. On simple swards, animals may be constrained with respect to both choice of diet and intake of DM, and nutrient contents of herbage can be determined with reasonable accuracy. As the majority of free-ranging herbivores exist in heterogeneous environments, the determination of intake would usually necessitate an accompanying estimation of diet composition. In this present review existing methodologies for quantifying diet composition and intake in free-ranging herbivores are discussed and the potential ways of overcoming the limitations of these techniques will be considered. We also address the possibility of modifying such methods to permit their use in non-ruminants and wild herbivores, grazing or browsing in complex vegetation environments. Recent advances in measurement techniques, in particular in the use of various marker substances and sampling equipment, offer the potential for studying the utilization of certain nutrients by free-ranging herbivores; these will also be discussed.

Intake can be estimated from the depletion of a food resource through grazing or browsing. While conceptually simple, such plant-based methods are reliable only over a very short time scale because of continuing plant growth, and are thus not applicable for continuously grazed areas. Likewise, exclusion cages may give an indication of changes in vegetation cover, when ungrazed over an extended period, but they do not provide a reasonable measure of intake. Whilst such plant-based methods may be useful in helping to evaluate other measurement techniques (for example see Reeves et al. 1996), they have limited applicability and will not be discussed further in this review.

The main advantages of 'animal-based' methods over 'plant-based' methods are that separate estimates of intakes for individuals within a group can be made, although, for reasons mentioned below, such measurements may not always be completely independent of each other. Moreover, such estimates may be used for longer-term studies, such as continuously grazed systems of pasture management. For many years, the most widely used animal-based method for estimating intake, especially in pasture-based systems, has been from separate estimates of faecal output and diet digestibility. This method is applicable over a wide range of situations and is compatible with many nutritional measurements; it is also amenable to further development and application. We describe a number of other animal-based methods, including the use of measurements of foraging behaviour to derive an intake estimate (bite rate $\times$ bite size $\times$ biting time), and using estimates of the turnover of a dietary component (e.g. $\mathrm{H}_{2} \mathrm{O}$ ) within the animal. Before these animal-based techniques are addressed in detail it is apposite to consider first the measurement of diet composition. Methods used to estimate the intakes of supplementary feed and soil in free-ranging herbivores will be considered as special examples of the estimation of diet composition.

\section{Approaches to the estimation of diet composition}

Animal-based methods involve the measurement, in samples collected from animals, of chemical or physical components which can be uniquely associated with or partitioned between the 
respective plant species on offer. This approach includes methods based on the quantification of microscopic fragments of plant material in extrusa from oesophageal-fistulated animals, stomach contents, digesta or faeces. Other methods include the estimation of $\mathrm{C}$-isotope ratios in such samples or in animal tissues (e.g. hair or wool) and the use of plant-wax components as markers.

The advantages and disadvantages of these various methods have been discussed extensively elsewhere (Holechek et al. 1982; Dove \& Mayes, 1996, 1999; Cornelis et al. 1999) and only a brief description of some of their attributes will be presented here.

\section{Use of oesophageal-fistulated animals for the estimation of diet composition}

Whilst oesophageal-fistulated animals have been used mostly to obtain samples for in vitro estimates of herbage digestibility (see later), they have also been used to estimate the botanical composition of the consumed diet, especially in studies with domestic herbivores (for example see Coates et al. 1987; Salt et al. 1994; Dove, 1998). In most circumstances extrusa samples have been used to infer the diet selected by a separate group of intact animals grazing or browsing the same resource. The assumption that such extrusa samples represent the composition of the diet of the intact test animals may be questioned for the following reasons:

(1) extrusa samples are collected over a period of a few minutes, whereas the test animals may be grazing or browsing an area for days or weeks. Whilst repeated extrusa collections may give a more representative estimate of diet composition, the total period of extrusa collection is likely to remain much less than the representative grazing period of the test animals,

(2) the diet selected by oesophageal-fistulated animals may differ from that of the test animals, owing to the former animals having been surgically prepared, handled and managed differently or being in a different physiological state;

(3) the composition of extrusa may differ from that of the plant material ingested, owing to chewing, the addition of saliva and the possibility of plant solubles and small fragments bypassing the fistula.

There is no absolute way to test the validity of these assumptions. However, reasonable assessments can be made through comparisons using alternative techniques for the estimation of diet composition. Such approaches, relevant to procedures involving oesophageal-fistulated animals, are discussed later in this review. There are, however, other means of addressing potential limitations of the use of these animals. The development of a 'remote control' valve for the collection of oesophageal extrusa may help overcome the problem of the short collection period (Raats et al. 1996), since the valve permits samples of herbage to be collected throughout the day without disturbing normal grazing behaviour. The addition of saliva to ingested plant material during chewing precludes the use of extrusa samples for studies of $\mathrm{Na}$ and P status, unless correction is made for the salivary input (for example see Langlands, 1987). Saul et al. (1986) suggested that the water-soluble carbohydrate content of extrusa samples may not reflect that of the diet, owing to soluble material bypassing the fistula. For most other feed components (e.g. $\mathrm{N}$ and fibre fractions) and for digestibility, published data suggest there is little effect of chewing and that extrusa samples can be used to represent the dietary levels of these components (Saul et al. 1986; Langlands, 1987).

\section{Microhistological procedures}

Many variants of the procedure have been described but, in principle, all rely on the identification of plant tissue fragments in prepared samples of oesophageal extrusa, stomach contents 
or faeces (Holechek et al. 1982). The composition of the diet can then be described in terms of the proportion of (identifiable) fragments coming from each plant species. Calibrations may be required to convert the resultant diet composition to a DM basis. In most cases, epidermal cuticular fragments are observed and identified, though differences in opaline phytoliths between plant species have also been proposed as an identification aid (Matsumoto \& Sugawara, 1997).

The method has been used extensively, especially with samples of stomach contents from dead wild animals (Holechek et al. 1982; Cornelis et al. 1999), in which such measurements would reflect mainly the composition of the last meal, and repeated measurements in the same animal are not possible. Also, the supply of suitable animals may be limited. Repeated samples of stomach contents for microhistological analyses could be obtained from ruminants fitted with a large rumen fistula (for example see Mohammad et al. 1995). Faecal sampling is much less restricted, allows repeated sampling and is also more appropriate for endangered animals and for domestic animals in which slaughter is too costly. Nevertheless, it has some major disadvantages, the main being the effect of differential digestion of fragments from different plant species. Moreover, as with almost all microhistological methods, the use of either stomach-contents or faeces samples can result in a large number of fragments which cannot be identified as being from particular species; this can render the method unreliable for quantitative estimation of diet composition. However, in such cases microhistological methods can still be useful in indicating the presence or absence of a particular plant species or plant part in the diet.

\section{Stable carbon isotope discrimination}

The ratio of the stable isotopes ${ }^{13} \mathrm{C}$ and ${ }^{12} \mathrm{C}$ in plant tissues differs between plants which have the $\mathrm{C}_{3}$ and $\mathrm{C}_{4}$ pathways of photosynthesis. This difference $\left(\delta^{13} \mathrm{C}\right)$ can be exploited to estimate the proportion of $\mathrm{C}_{3}$ and $\mathrm{C}_{4}$ herbage in a mixture (Jones et al. 1979; Tieszen et al. 1983). In tropical ecosystems, $\mathrm{C}_{3}$ plants are represented principally by legumes, forbs and browse, whilst $\mathrm{C}_{4}$ plants are represented mainly by tropical grasses and some forbs. This distinction has permitted the estimation of the proportion of these different plant types in the diet of herbivores, using the $\delta^{13} \mathrm{C}$ value in extrusa from oesophageal-fistulated animals or in faeces (for example see Coates et al. 1987), or animal tissue (for example see Tieszen et al. 1983). The method cannot resolve diet composition to the species level, but estimation of the proportion of legume in the diet is still important, since the legume has a higher $\mathrm{N}$ content and may contribute much of the dietary $\mathrm{N}$ intake. Unfortunately the method is of limited use in colder areas of the world, where very few plants exhibit the $\mathrm{C}_{4}$ photosynthetic pathway. The effect of differential digestion of different plant species must also be considered. When faeces samples are used, the method will tend to underestimate the intake of plants of high digestibility, since less of their C remains in faeces. Conversely, the use of animal tissues, such as wool or hair, which give a long-term indication of dietary ratios of $\mathrm{C}_{3}$ and $\mathrm{C}_{4}$ plants, will underestimate the dietary contribution of plants with lower digestibility.

\section{Plant-wax markers for the estimation of diet composition}

Plant cuticular waxes are complex mixtures of many classes of compounds, the composition of the mixture varying with different plant species or plant parts. Although such differences in wax composition could potentially be exploited to estimate diet composition using various 
compound types, to date only the $n$-alkanes of plant cuticular wax have been widely investigated as markers. In most higher plants, $n$-alkanes with odd-numbered $\mathrm{C}$-chains in the range $\mathrm{C}_{21}-\mathrm{C}_{37}$ comprise most of the hydrocarbons of cuticular wax. Plant species differ in the composition of this fraction (for example see Dove, 1992; Mayes et al. 1994). Differences in alkane pattern can be used to estimate the proportions of different plant species or plant parts in herbage mixtures (Dove, 1992) or extrusa from oesophageal-fistulated animals (Salt et al. 1994; Dove et al. 1999) by calculating the combination of alkane profiles from the plants on offer which accounts for the observed alkane pattern in the mixture. The method is equally applicable for the estimation of the composition of digesta samples or the diet composition from faeces samples collected from either domestic animals (Salt et al. 1994; Dove et al. 1999) or wild species (Hulbert, 1993; Woolnough, 1998; MN Bugalho, RW Mayes and JA Milne, unpublished results). The recovery of alkanes in faeces is high but incomplete and, in ruminants, varies according to chain length. Thus when digesta or faeces samples are used, their alkane concentrations must be corrected for differences in recovery (Dove \& Mayes, 1996; Dove et al. 2000).

With simple mixtures, calculations of dietary composition can be made using simultaneous equations (Dove, 1992), with the number of alkanes chosen as markers being equal to the number of dietary components. However, using a least-squares procedure allows the use of more alkanes than there are components (plant species and/or plant parts) in the mixture; this is because least-squares procedures search for the best fit rather than a unique solution (as obtained using simultaneous equations). Estimates of the species composition of herbage mixtures obtained from simultaneous equations were almost identical to those derived from least-squares procedures (Dove \& Moore, 1995). Woolnough (1998) reached a similar conclusion in comparing alkane-based estimates of the diet composition in free-ranging populations of eastern grey kangaroos (Macropus giganteus) and northern hairy-nosed wombats (Lasiorhinus krefftii). A number of different algorithms have been used in the least-squares procedures. Mayes et al. (1994), using the 'Solver' routine within the 'Excel' spreadsheet program (Microsoft), minimized the sum of the squared discrepancies between the measured faecal proportions of individual alkanes (expressed relative to the total faecal alkane), and alkane proportions (of the total alkane) calculated from the alkane compositions of component plant species. Dove \& Moore (1995) and Newman et al. (1995) used different non-negative least-squares procedures applied to faecal and plant alkane concentrations to estimate the intakes of plant components necessary to produce $1 \mathrm{~kg}$ faecal DM (or OM); diet composition could subsequently be calculated from these hypothetical intake values. Hameleers \& Mayes (1998a) compared these three least-squares procedures and observed that they gave almost identical estimates of diet composition in dairy cows.

Plant wax alkanes, as markers to estimate diet composition, offer numerous advantages over alternative measurement methods. Estimates are conducted over, and are relevant to, a similar time scale to that required in nutritional studies. Sampling of dietary components and faeces is relatively simple and is potentially applicable to both domestic and wild herbivores, and chemical analysis is both straightforward and accurate. Furthermore, concurrent estimates of intake are possible (see later). However, the use of marker patterns (of which plant alkanes are but one example) to estimate diet composition is a relatively novel concept and there are a number of aspects which need to be addressed in order to evaluate and optimize the technique. In particular:

(1) more validations of the technique are required;

(2) procedures for statistical analysis of diet composition data need to be developed; 
(3) potential weighting procedures to optimize the discriminatory power of diet composition markers need to be explored;

(4) procedures need to be developed that allow marker systems to be used in situations where the number of potential dietary components exceeds the number of available markers.

To date, validations of diet composition estimates, carried out indoors by feeding known mixtures to livestock, have largely been confined to two-component mixtures (Dove \& Mayes, 1991, 1996), though estimates of composition of herbage mixtures have involved up to ten species (Hoebee et al. 1998). Although not yet proven, the accuracy of diet composition estimates is likely to decline as the number of dietary components increases. There is clearly a need to make rigorous tests of the method using more complex dietary mixtures.

It is logical to assume that the most accurate estimates of diet composition will be obtained when all dietary components have similar total alkane levels, but where their patterns differ greatly. Multivariate statistical procedures such as principal components analysis or canonical variates analysis can indicate the degree to which alkane patterns differ between plant species on offer (Dove et al. 1999; MN Bugalho, RW Mayes and JA Milne, unpublished results), but further statistical procedures are required in order to establish confidence limits to resultant diet composition estimates. These will be affected by the nature of the various alkane patterns of the dietary components and by analytical error, sampling errors and intrinsic variation in the alkane compositions within individual dietary components.

For particular mixtures, the individual alkanes which differ most in relative concentration between components would be expected to be more effective as diet composition markers than those alkanes with similar levels in all components. Using existing algorithms, alkanes with the highest absolute concentrations have the greatest influence on the resultant diet composition estimate. In order to optimize the calculation procedure there is a case for adjusting the weighting of individual alkanes, such that those which differ more, in relative terms, between dietary components should have a greater influence on the diet composition estimate. It may also be beneficial to weight against those alkanes with greater analytical errors or withincomponent variability. An extreme form of weighting is the omission of certain alkanes from particular diet composition estimations; this can improve estimates of diet composition (Dove et al. 1999).

In theory, the maximum number of components that can be separated using alkanes is equal to the number of alkane markers available (about fifteen), but since many of the alkanes may be present at low concentrations, the practical limit may be less than fifteen. However, in complex associations such as rangelands or shrublands, there can be more than this number of plant species on offer to the herbivore (MN Bugalho, RW Mayes and JA Milne, unpublished results). To overcome this problem and extend the alkane procedure to complex plant associations, there are three possible options: (1) combine the discriminatory powers of this and other methods of estimating diet composition; (2) decrease the number of plant pools to be discriminated; (3) increase the number of markers with which to discriminate.

An example of the combination of methods is the successful use, by Salt et al. (1994), of both microhistological and alkane procedures to estimate diet composition in sheep which could choose to graze any combination of either Deschampsia flexuosa grassland or Calluna vulgaris heathland. A second possibility might be the combination of the alkane method with the discriminatory power of near i.r. reflectance spectroscopy for diet composition (Walker et al. 1998). A reduction in the number of plant pools to be discriminated could be based on preliminary information based on other techniques (e.g. observation of the animals, microhistological, near i.r. reflectance spectroscopy) which establish those plants not selected. 
Another option would be to group the individual plant species which had statistically indistinguishable alkane profiles (for example see Woolnough, 1998; MN Bugalho, RW Mayes and JA Milne, unpublished results). Resultant estimates of diet composition would thus be expressed in terms of the plant groups. For example, MN Bugalho, RW Mayes and JA Milne (unpublished results) grouped grass and forb species as a single 'herbage' component in studies with wild red deer which ingested mainly browse species. The acceptability of the diet composition estimates obtained after such grouping depends upon the purpose to which the results will be put. Provided the grouping does not adversely affect the accuracy of the actual determination of diet composition, then the results would be a valid estimate of, as in the above example, browse species plus a grouped 'herbage' component (MN Bugalho, RW Mayes and JA Milne, unpublished results). However, regardless of their having similar alkane profiles, the grouping of potential dietary components would not be appropriate if the individual components of the group had, for example, different $\mathrm{N}$ contents and the diet composition estimates were being used to estimate $\mathrm{N}$ intake. A third approach would be to increase the number of markers available for use in the calculation of diet composition. We have discussed in detail elsewhere the potential to use other plant wax compounds including alkenes, branched-chain alkanes, alcohols, sterols and possibly long-chain fatty acids as additional markers (Dove \& Mayes, 1996, 1999). The long-chain alcohols of cuticular wax show particular promise, since they are often present in large amounts in plants which have low concentrations of alkanes (Dove \& Mayes, 1999).

\section{Comparison of diet composition estimates obtained using different techniques under field conditions}

Under field conditions, one cannot validate estimates of diet composition but can only compare measurements made using different techniques. However, such information can be valuable with respect to technique assessment. The development of the alkane method, in particular, has allowed important reassessments to be made of the validity of using oesophageal-fistulated animals to sample grazed vegetation. The data in Table 1 represent one of the few comparisons (Dove, 1998) of the respective species composition of the herbage on offer, the diet of oesophageal-fistulated animals at a single grazing of that herbage, and the diet of the same animals over a period of $7 \mathrm{~d}$. The extent to which these three compositions agreed depended on the nature of the pasture on offer.

On the clover-dominant pasture, the proportions of clover in the extrusa from oesophagealfistulated animals, and the diet consumed by these animals over $7 \mathrm{~d}$, were moderately but significantly higher than the sward clover content $(P<0.05)$. There was also apparent selection against the weed species Rumex acetosella $(P<0 \cdot 001)$. By contrast, over $7 \mathrm{~d}$ the oesophagealfistulated animals grazing the ryegrass-dominant sward consumed a diet which did not differ in overall species composition from that of the sward $(P>0.05)$. However, the extrusa collected from a single grazing had a markedly different content of Phalaris $(P<0.001)$, ryegrass $(P<0.001)$ and $R$. acetosella $(P<0.05)$.

This approach has allowed some assessment of the errors arising from the assumption that the single sample of extrusa from an oesophageal-fistulated animal represents the longer-term diet. The alkane method has also allowed reliable comparisons to be made between the botanical and nutrient composition of extrusa samples and the actual diet of intact test animals. Such comparisons have been made using microhistological procedures, but results have been variable, owing in part to difficulties with this technique. Coates et al. (1987) compared estimates 
Table 1. Comparison of the botanical composition (\% dry matter) of subterranean clover-dominant or perennial ryegrass-dominant pastures ('herbage') with the botanical composition of the diet selected by oesophagealfistulated sheep at a single grazing ('extrusa'), or by the same sheep over a period of $7 \mathrm{~d}$ ('diet')*

(Mean values for six oesophageal-fistulated sheep per pasture)

\begin{tabular}{lccr}
\hline & \multicolumn{3}{c}{ Botanical composition (\% dry matter) } \\
\cline { 2 - 4 } Pasture & Herbage & Extrusa & Diet \\
\hline Clover dominant: & & & \\
$\quad$ Trifolium subterraneum & 69.9 & 84.3 & 91.5 \\
$\quad$ Lolium perenne & $2 \cdot 8$ & 0 & 0.8 \\
Rumex acetosella & 2.5 & 6.8 & 5.1 \\
Other grasses & 4.7 & & 3.4 \\
Grass dominant: & 11.1 & 72.8 & \\
$\quad$ Phalaris aquatica & 71.4 & 16.3 & 4.3 \\
Lolium perenne & 13.4 & 8.6 & 70.4 \\
Rumex acetosella & 4.2 & 2.4 & 2.8 \\
Other grasses & & 22.6 \\
\hline
\end{tabular}

* Recalculated from data presented by Dove (1998). Botanical composition of herbage by hand-sorting; botanical composition of extrusa and of the diet estimated from the pattern of alkane concentrations in herbage components, and extrusa or faeces samples (bulked: herbage, 18 or 26 October for clover-dominant or grass-dominant pasture respectively; extrusa 22 October; diet, 14-20 October). Calculations performed using EatWhat procedure of Dove \& Moore (1995).

of the composition of extrusa collected by steers and the diet of cattle resident on tropical grass-Stylosanthes spp. pastures. Although estimates of the legume content of extrusa based on $\mathrm{C}$-isotope and microhistological procedures were comparable, agreement between the legume content of extrusa and of the diet of the resident animals, estimated from the C-isotope ratio in their faeces, was poor. The authors therefore suggested that the assumptions concerning the use of oesophageal-fistulated animals should not be accepted without supporting evidence for their validity.

Dove et al. (2000) suggested that if oesophageal-fistulated and intact test animals were consuming similar diets, then the alkane compositions of extrusa should be similar to those in the faeces from test animals (corrected for incomplete recovery). Fig. 1 shows the relationship between the alkane composition (expressed as proportions of the total alkane content) of extrusa samples from adult oesophageal-fistulated wethers and that of faeces from pregnant ewes grazing the same grass-dominant pasture. The faecal data were corrected using recoveries obtained from total faecal collections in grazing wethers (Dove et al. 2000). The fitted regression through these data did not differ from the line of equality. This suggests that, in a grazing bout of 20-30 min, the oesophageal-fistulated wethers were selecting the same diet as that selected by the ewes over the $6 \mathrm{~d}$ faecal sampling period. Note that this is not absolute proof, since it is theoretically possible to consume diets of very similar alkane proportions but differing in species composition. This is more likely to be a problem with complex associations of plant species than with the simple swards used in this example. Although the results in Fig. 1 suggest that the oesophageal-fistulated animals and test animals consumed similar diets, there is ample evidence that this is not always the case (for example see Coates et al. 1987; Dove, 1998). In contrast to microhistological or C-isotope methods, this approach is equally applicable to the estimation of the composition of extrusa or consumed diets in terms of plant parts (Dove et al. 1999).

\section{The estimation of intake from faecal output and diet digestibility}

Intake can be estimated from the relationship which exists between the intake of a diet, its indigestibility ( 1 - digestibility) and the resultant faecal output. Conventionally, this approach 


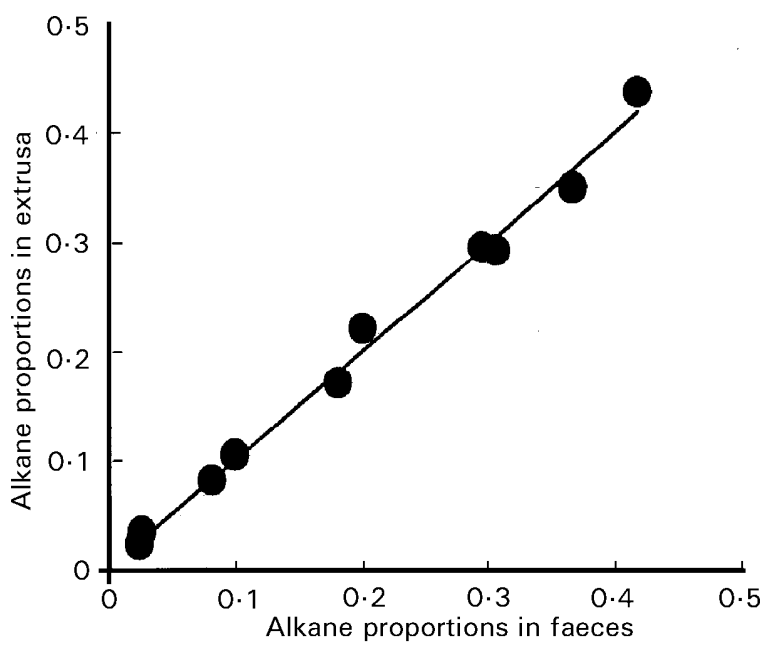

Fig. 1. Relationship between the alkane composition (concentration for each alkane expressed as a proportion of the total alkane content) of extrusa from oesophageal-fistulated wethers and that in the faeces of pregnant ewes grazing the same pasture $\left(y=0.987 x+0.005, R^{2}=0.993\right.$; Dove et al. 2000).

is used to estimate the intake of DM or OM, but in principle can be applied to any nutrient or other substance in the diet. Because it is necessary to have a sample representative of the whole diet, in heterogeneous environments an accompanying estimate of diet composition would be required, unless it has been confidently established that a sample of mixed vegetation (e.g. extrusa) truly represents the diet of the test animal.

\section{Faecal output}

The principles of faecal output measurement in free-ranging animals are straightforward. Faecal output can be measured directly by total collection over a number of days, using bags attached to harnesses. The main concerns regarding this method are to ensure that no faeces are spilt and that the animals' normal behaviours are not compromised by the collection equipment or procedures. Less restrictive to the animals is the estimation of faecal output by dilution in the faeces of an external marker which is administered orally to the animal daily (or more frequently) over a period of 10-14d. This allows the faeces to be sampled over a 5-7 d period, after the marker concentration has equilibrated in the faeces. Various markers have been used (Table 2), $\mathrm{Cr}_{2} \mathrm{O}_{3}$ being the most popular, but there has been recent concern over its potential carcinogenic properties. The main problems with the external marker approach relate to the properties of the markers themselves, especially incomplete faecal recovery. Diurnal variation in faecal marker concentration is another problem encountered (Dove et al. 2000). Attempts have been made to reduce this effect, either by careful selection of dosing and sampling times or through modifying the matrix in which the marker is dosed. More details about the use of daily-dosed external markers for estimation of faecal output are given elsewhere (for example see Le Du \& Penning, 1982). 
Table 2. Some faecal markers used for the estimation of faecal output in herbivores (see Kotb \& Luckey, 1972; Udén et al. 1980; Dove \& Mayes, 1996)

\begin{tabular}{|c|c|c|c|c|c|}
\hline Marker & Type & Analysis* & Recovery & $\begin{array}{l}\text { Digesta } \\
\text { association }\end{array}$ & Additional uses \\
\hline $\begin{array}{l}\mathrm{Cr}_{2} \mathrm{O}_{3} \dagger \\
\mathrm{TiO}_{2} \dagger \\
\mathrm{BaSO}_{4} \dagger \\
\mathrm{Ce}, \mathrm{Dy}, \mathrm{Er}, \mathrm{Eu}, \mathrm{Yt}, \mathrm{Yb} \dagger \\
\mathrm{Ru}-\text {-phenanthroline } \dagger \\
\text { Cr-mordanted fibre } \\
\text { Plastic particles } \\
\text { Artificial alkanes } \\
\text { CrEDTA } \\
\text { CoEDTA } \\
\text { Polyethylene glycol }\end{array}$ & $\begin{array}{l}\text { Insoluble oxide } \\
\text { Insoluble oxide } \\
\text { Insoluble salt } \\
\text { Soluble rare earths } \\
\text { Soluble complex } \\
\text { Bonded to fibre } \\
\text { Insoluble polymer } \\
\text { Insoluble wax } \\
\text { Soluble complex } \\
\text { Soluble complex } \\
\text { Soluble polymer }\end{array}$ & $\begin{array}{l}\text { AA or XRF } \\
\text { AA or XRF } \\
\text { XRF } \\
\text { AA or XRF } \\
\text { AA or XRF } \\
\text { AA or XRF } \\
\text { Physical } \\
\text { GC } \\
\text { AA or XRF } \\
\text { AA or XRF } \\
\text { Turbidity }\end{array}$ & $\begin{array}{l}\text { Very high } \\
\text { Very high } \\
\text { Very high } \\
\text { Medium/high } \\
\text { High } \\
\text { Very high } \\
\text { Very high } \\
\text { Medium/high } \\
\text { Medium/high } \\
\text { Medium/high } \\
\text { High }\end{array}$ & $\begin{array}{l}\text { None, dense } \\
\text { None, dense } \\
\text { None, dense } \\
\text { Mainly solid-phase } \\
\text { Mainly solid-phase } \\
\text { Solid-phase } \\
\text { None } \\
\text { Mainly solid-phase } \\
\text { Liquid-phase } \\
\text { Liquid-phase } \\
\text { Liquid-phase }\end{array}$ & $\begin{array}{l}\text { Supplement, CRD } \\
\text { Radiography } \\
\text { Digesta flow, rate of passage, supplement } \\
\text { Digesta flow, rate of passage } \\
\text { Rate of passage } \\
\text { Rate of passage, faecal identification } \\
\text { Intake, supplement, rate of passage, CRD } \\
\text { Digesta flow, rate of passage } \\
\text { Digesta flow, rate of passage } \\
\text { Digesta flow, rate of passage }\end{array}$ \\
\hline
\end{tabular}


The degree of disturbance caused by the daily dosing and the potential diurnal variation in faecal marker concentration can be reduced by using intraruminal controlled-release devices which, after placement in the rumen, release marker at a predictable constant rate for a period of 3-4 weeks. Devices delivering $\mathrm{Cr}_{2} \mathrm{O}_{3}$ have been commercially available and have been evaluated in a number of studies (for example see Furnival et al. 1991a,b).

Repeated daily dosing can also be avoided by collecting a series of faeces samples following a single dose of marker; faecal output can then be estimated from the area under the resultant faecal concentration $\times$ time curve. Such areas have been assessed either by integrating a mathematical function derived from the curve (for example see France et al. 1988) or, for a complete curve, by calculating the area as the sum of a series of trapezia (Galyean, 1993), as shown in Fig. 2. The first method provides additional information on digesta kinetics, such as passage rate, but the times of faecal sampling (or defecations) are required and the required frequency of faecal sampling may cause unreasonable disturbance to animals. Using the 'trapezium' method, the time and frequency of faecal sampling are less important; even if the time sequence of the faecal samples is incorrect, errors in area estimation are small (typically $<5 \%$ ). Thus the 'trapezium' method would be more appropriate in situations where the frequency of faeces sampling is limited. Furthermore, for faeces collected from the ground, the 'trapezium' method could be used to estimate faecal output when the actual times of defecation are not known. Although there appear to have been no direct comparisons of faecal output estimates obtained from single and repeated daily doses of marker, it could be expected that variation in daily faecal output rate during the sampling period could lead to greater errors for the former method.

\section{Estimation of digestibility}

Obtaining reliable estimates of digestibility represents a greater problem than measurement of faecal output, because errors in the estimation of digestibility will always cause a larger error in the resultant intake estimate, especially at higher digestibilities (Langlands, 1987; Dove \& Mayes, 1996). The main difficulty is in obtaining a digestibility estimate which represents the diet consumed by the grazing or browsing animal. Even on single-species grass pastures, where

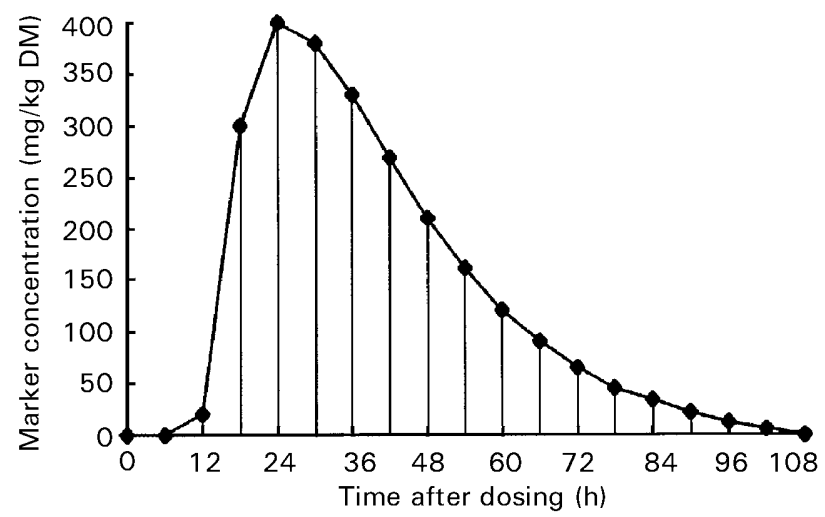

Fig. 2. Stylized representation of the 'trapezium' method for estimating the area under a faecal marker concentration $v$. time curve following a single administration of an external marker with a fixed sampling interval. 
the scope for variation in diet composition is limited, this is not easy. An approach, popular some years ago, is to use as an index of diet digestibility a component such as $\mathrm{N}$, the faecal concentration of which is correlated with herbage digestibility (Le Du \& Penning, 1982). Indoor trials with herbage closely similar to that of the experimental pasture are necessary to derive the relationship between the faecal concentration of the component and digestibility. Recently the faecal index method has been reassessed for a range of grass swards using a generalized regression equation with faecal $\mathrm{N}$ and faecal acid-detergent fibre as indices (Comeron \& Peyraud, 1993). The most widely used method has been to measure digestibility in vitro. Although calibrations of in vitro $\times$ in vivo digestibility are necessary to obtain a predicted in vivo value, the number of indoor trials required to obtain such regressions is small. The original two-stage method of Tilley \& Terry (1963) requires fresh rumen contents, which can be a disadvantage over cellulase-pepsin incubation. Bacterial cultures from ruminant faeces have also been used in place of rumen contents, (for example see Akhter et al. 1999).

These approaches, while in widespread use, have major disadvantages. Firstly, it has to be assumed that the same diet digestibility applies to all individuals in a group of animals grazing the same pasture; no allowance is made for individual-animal variation in digestibility, nor for the fact that digestibility is itself affected by intake (Le Du \& Penning, 1982). Furthermore, the ages and physiological states of the animals used in the indoor calibration trials often differ from those of the test animals. Samples for in vitro analysis have frequently been provided by oesophageal-fistulated animals, the drawbacks of which have been discussed earlier. A further problem arises when consumed vegetation is only one of the components of a mixed diet, since the digestibility estimate required to determine intake should represent that of the whole diet. The difficulty in predicting whole-diet digestibility is further exacerbated when digestive interactions occur: for example, starchy components, such as cereal concentrates, can reduce the digestibility of roughages, such as herbage (for example see Dixon \& Stockdale, 1999).

These problems can be largely overcome by using indigestible diet components as internal markers. Digestibility is estimated from the relative concentrations of internal marker in the diet and in faeces (i.e. 1 - diet: faeces concentration ratio). Since the faeces come from individual experimental animals, separate digestibility estimates for each animal are obtained. However, if the diet sample is considered, in terms of marker concentration, to represent material ingested by a group of test animals, the resultant digestibility estimates for the individuals are not strictly independent. With the internal marker method, the problem of obtaining a representative sample still exists; the scale of the problem compared with that incurred with the in vitro digestibility method depends upon the relative sampling variabilities for in vitro digestibility and the internal marker.

The internal marker method allows whole-diet digestibility to be determined when animals are receiving mixed diets, if the concentration of the internal marker in the complete diet can be estimated. When grazing animals are receiving feed supplements, the intake and the internalmarker concentration of the supplement must be known; this is not normally a problem as methods are available for estimating supplement intake (see later).

Some of the dietary components which have been investigated as internal markers are detailed in Table 3. Despite the potential advantages of using an internal marker to estimate digestibility, until recently the approach has been unsatisfactory, largely because the markers have failed to meet the criteria required of an 'ideal' marker (Kotb \& Luckey, 1972). Many of the components used as internal markers have been characterized by inconsistent faecal recovery, mainly because most have not been discrete compounds. Their empirical nature means that it is uncertain whether a component measured in the faeces is the same entity as that measured in the diet. It is not clear whether low apparent recoveries in faeces are due to 
Table 3. Some internal faecal markers used for estimating digestibility in herbivores (see Kotb \& Luckey, 1972; Penning \& Johnson, 1983a,b; Smith, 1989; Dove \& Mayes, 1996)

\begin{tabular}{|c|c|c|c|c|c|}
\hline Marker & Type & Analysis & Recovery & Digesta association & Additional uses \\
\hline $\begin{array}{l}\text { Lignin } \\
\text { Acid-detergent lignin } \\
\text { Indigestible ADF } \\
\text { Indigestible NDF } \\
\text { PIC } \\
\text { Acid-insoluble ash } \\
\text { Silica } \\
\text { Chromogen } \\
\text { Long-chain fatty acids } \\
\text { Long-chain } n \text {-alkanes }\end{array}$ & $\begin{array}{l}\text { Fibre fraction } \\
\text { Fibre fraction } \\
\text { Fibre fraction } \\
\text { Fibre fraction } \\
\text { Fibre fraction } \\
\text { Silicaceous } \\
\text { Silicaceous } \\
\text { Plant pigments } \\
\text { Plant-wax compound } \\
\text { Plant-wax compound }\end{array}$ & $\begin{array}{l}\text { Extraction residue (empirical) } \\
\text { Extraction residue (empirical) } \\
\text { Extraction residue (empirical) } \\
\text { Extraction residue (empirical) } \\
\text { Extraction residue (empirical) } \\
\text { Extraction residue (empirical) } \\
\text { Various (discrete) } \\
\text { Colorimetric (empirical) } \\
\text { Gas chromatography (discrete) } \\
\text { Gas chromatography (discrete) }\end{array}$ & $\begin{array}{l}\text { Variable } \\
\text { Variable } \\
\text { Variable } \\
\text { Variable } \\
\text { Variable } \\
\text { High } \\
\text { High } \\
\text { Variable } \\
\text { High } \\
\text { Medium/high }\end{array}$ & $\begin{array}{l}\text { Solid-phase } \\
\text { Solid-phase } \\
\text { Solid-phase } \\
\text { Solid phase } \\
\text { Solid-phase } \\
\text { Solid-phase? } \\
\text { Solid-phase? } \\
\text { Uncertain } \\
\text { Mainly solid-phase } \\
\text { Mainly solid-phase }\end{array}$ & $\begin{array}{l}\text { Rate of passage } \\
\text { Rate of passage* }\end{array}$ \\
\hline
\end{tabular}

ADF, acid-detergent fibre; NDF, neutral-detergent fibre; PIC, potentially indigestible cellulose. 
transformations of marker components in the gut, to absorption or to inconsistencies in analytical procedures. This may explain why a particular marker may be highly effective in some studies but useless in others.

With the exception of plant silica, for which soil contamination of analysed herbage can affect the reliability of digestibility estimates, it is only within the last 20 years that discrete compounds have been considered as internal markers for determining digestibility (Grace \& Body, 1981). Whilst none of these compounds yet investigated could be considered to be an 'ideal' internal marker, the advantages over 'empirical' markers of having reliable analytical techniques and the ability to assess their behaviour in the digestive tract, whether through transformation or absorption, makes discrete markers potentially very useful in a wide range of situations. There is also potential for other plant compounds, not yet considered, to be effective internal markers.

\section{Intake measurements using n-alkanes as markers}

Plant wax $n$-alkanes were originally suggested as internal markers for estimating digestibility (Mayes \& Lamb, 1984), since they are discrete compounds and are easily analysed. The concept of estimating intake by the concurrent use of two $n$-alkanes of adjacent chain length was first considered by Mayes et al. (1986a). In effect, a plant-wax (odd-chain) alkane is used as an internal digestibility marker, at the same time as a dosed even-chain alkane as a faecaloutput marker. Whilst both digestibility and faecal-output estimates would be biased because of incomplete faecal recoveries, resultant intake estimates will be unbiased if the faecal recoveries of the two markers are the same. For plant odd-chain alkane, $i$, and dosed even-chain alkane, $j$ :

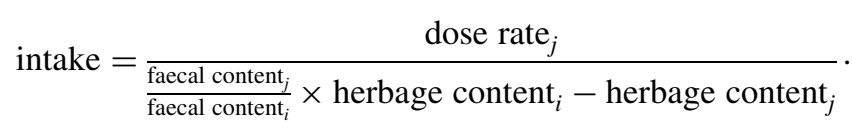

Note that the presence of the even-chain alkane in the diet is taken into account. Using dosing regimens similar to that most commonly used for $\mathrm{Cr}_{2} \mathrm{O}_{3}$, numerous studies have demonstrated in sheep, cattle and goats that plant $\mathrm{C}_{33}$ and dosed $\mathrm{C}_{32}$ alkanes have very similar faecal recoveries and thus give estimates of herbage intake with very little bias (Dove \& Mayes, 1991, 1996).

The alkane method for estimating intake offers a number of advantages over other techniques. It gives individual-animal intakes and can be used where animals are receiving feed supplements. Also, GC analysis allows both plant and dosed markers to be determined at the same time, which limits analytical error and bias. Since the ratio of the concentrations in faeces is used, it is not necessary to obtain absolute faecal concentrations. Direct comparisons of intake estimates using the alkane and in vitro digestibility-faecal output $\left(\mathrm{Cr}_{2} \mathrm{O}_{3}\right)$ methods indicate the superiority of the alkane method for both cattle (Malossini et al. 1996) and sheep (Dove et al. 2000).

Direct comparisons of herbage intakes estimated using the alkane method and the in vitro digestibility-faecal output $\left(\mathrm{Cr}_{2} \mathrm{O}_{3}\right)$ method have been conducted with sheep (Piasentier et al . 1995; Dove et al. 2000) and with dairy cows (Malossini et al. 1996). In both housed and grazing sheep, Piasentier et al. (1995) found that intakes estimated using the in vitro-Cr procedure were always higher than those estimated using $\mathrm{C}_{31}: \mathrm{C}_{32}$ alkanes, especially at higher intakes. Malossini et al. (1996) also reported an effect of level of intake on the discrepancy between the two methods, though in their case, when the daily intakes of dairy cows were 
above $14 \mathrm{~kg} \mathrm{OM}$, the in vitro- $\mathrm{Cr}$ procedure gave higher estimates whilst the alkane procedure $\left(\mathrm{C}_{31}: \mathrm{C}_{32}\right)$ gave higher estimates below $14 \mathrm{~kg} \mathrm{OM} / \mathrm{d}$.

More recently, Dove et al. (2000) demonstrated effects of both level of intake and physiological state (late pregnancy $v$. early lactation $v$. mid lactation) on the relationship between these methods in grazing ewes. They also showed that the major contributor to the discrepancy between the methods was the failure of in vitro estimates of digestibility to be representative of herbage digestibility in vivo. A recalculation of some of their data is shown in Table 4.

In ten of the twelve possible comparisons (four treatments, three stages), the in vivo and in vitro estimates of herbage digestibility differed significantly. Where the in vivo estimate was higher, the alkane-based estimate of intake was the higher of the two (positive discrepancy); when in vivo estimates were significantly lower, so also was the alkane-based estimate of intake (negative discrepancy). Where there was no significant difference between the two estimates of digestibility, there was no consistent difference in the discrepancy between the two estimates of intake (one positive, one negative). The presence or absence of supplement had no effect on these relationships. These observations are consistent with the explanation that the alkane procedure accommodated the difference in the digestibility estimates and resulted in a different estimate of intake (Dove et al. 2000). The significant differences in the in vivo and in vitro estimates of digestibility relate mainly to the effects of level of intake and physiological state on gut transit times (Dove et al. 2000). From the comparisons to date, it is clear that no simple relationship should be expected between herbage intake estimates based on alkanes compared with the in vitro-Cr procedure.

In common with other intake methods requiring the analysis of dietary samples, the feed sample must be representative, with respect to its alkane content, of the material ingested by the animals. As alkane concentrations can differ for different plant parts and plant species, care must be taken in sampling the vegetation for analysis. Although oesophageal-fistulated animals have been used to collect samples of ingested vegetation, for uniform swards, they have been shown to be unnecessary; hand-clipped grass samples are adequate. The concentrations of the predominant $n$-alkanes in hand-clipped herbage samples $(75 \mathrm{~m} \times 0.15 \mathrm{~m}$ area at $10 \mathrm{~mm}$ height above the soil surface) from a uniform Lolium perenne-Phleum pratense plot ( $0.48 \mathrm{ha})$ and in

Table 4. Comparison of the discrepancy between alkane-based $\left(\mathrm{C}_{32}: \mathrm{C}_{33}\right)$ and in vitro-Cr-based estimates of herbage intake, and the difference between in vivo and in vitro estimates of the digestibility of the herbage consumed by grazing ewes (recalculated from the data of Dove et al. (2000))

\begin{tabular}{|c|c|c|c|c|}
\hline State & $\begin{array}{l}\text { Grazing } \\
\text { pressure }^{*}\end{array}$ & Supplement & $\begin{array}{c}\text { Intake discrepancy } \\
(\mathrm{g} \mathrm{OM} / \mathrm{d}) \dagger\end{array}$ & $\begin{array}{c}\text { (In vivo }- \text { in vitro) } \\
\text { digestibility }\end{array}$ \\
\hline Pregnancy & $\begin{array}{l}\text { High } \\
\text { Medium }\end{array}$ & $\begin{array}{l}\overline{-} \\
+ \\
\overline{+}\end{array}$ & $\begin{array}{r}136 \\
56 \\
-109 \\
-144\end{array}$ & $\begin{array}{l}0.068(P<0.05) \\
0.115(P<0.05) \\
-0.041(P<0.05) \\
0.006(\mathrm{NS})\end{array}$ \\
\hline Early lactation & $\begin{array}{l}\text { High } \\
\text { Medium }\end{array}$ & $\begin{array}{l}- \\
+ \\
- \\
+\end{array}$ & $\begin{array}{l}134 \\
272 \\
410 \\
251\end{array}$ & $\begin{array}{l}0.052(P<0.05) \\
0.079(P<0.05) \\
0.101(P<0.001) \\
0.125(P<0.05)\end{array}$ \\
\hline Mid lactation & $\begin{array}{l}\text { High } \\
\text { Medium }\end{array}$ & $\begin{array}{l}- \\
+ \\
- \\
+\end{array}$ & $\begin{array}{r}-55 \\
-58 \\
397 \\
346\end{array}$ & $\begin{array}{r}-0.074(P<0.01) \\
-0.110(P<0.01) \\
-0.016(\mathrm{NS}) \\
0.043(P<0.05)\end{array}$ \\
\hline
\end{tabular}

OM, organic matter.

*High, 30.8 ewes/ha, mean herbage intakes $662-1218 \mathrm{~g} \mathrm{OM} / \mathrm{d}$; medium, $17.1 \mathrm{ewes} / \mathrm{ha}$, mean herbage intakes $904-$ $1874 \mathrm{~g} \mathrm{OM} / \mathrm{d}$.

† Intake estimated using $\mathrm{C}_{32}: \mathrm{C}_{33}$ alkane pair minus intake estimated using in vitro-Cr method.

S Significance levels of differences between in vivo and in vitro estimates of herbage digestibility in parentheses. 
Table 5. Comparison of $n$-alkane concentrations ( $\mathrm{mg} / \mathrm{kg}$ dry matter) in extrusa samples from oesophagealfistulated sheep grazing a Lolium perenne-Phleum pratense plot and hand-clipped samples taken from the same plot (data of G.R. lason, unpublished results)

(Mean values and standard deviations)

\begin{tabular}{|c|c|c|c|c|c|c|c|}
\hline Sample & $n$ & & $\mathrm{C}_{27}$ & $\mathrm{C}_{29}$ & $\mathrm{C}_{31}$ & $\mathrm{C}_{33}$ & $\mathrm{C}_{35}$ \\
\hline $\begin{array}{l}\text { Extrusa from oesophageal- } \\
\text { fistulated sheep }\end{array}$ & 5 & $\begin{array}{l}\text { Mean } \\
\text { SD }\end{array}$ & $\begin{array}{l}30 \cdot 8 \\
4.24\end{array}$ & $\begin{array}{r}56 \cdot 7 \\
5 \cdot 61\end{array}$ & $\begin{array}{c}89.5 \\
6.28\end{array}$ & $\begin{array}{l}89.3 \\
10.56\end{array}$ & $\begin{array}{c}13.8 \\
1.34\end{array}$ \\
\hline Hand-clipped herbage & 10 & $\begin{array}{l}\text { Mean } \\
\text { SD }\end{array}$ & $\begin{array}{c}31.8 \\
5.72\end{array}$ & $\begin{array}{l}56 \cdot 6 \\
8.86\end{array}$ & $\begin{array}{l}91.4 \\
10.62\end{array}$ & $\begin{array}{l}90 \cdot 6 \\
10.90\end{array}$ & $\begin{array}{c}14.0 \\
1.63\end{array}$ \\
\hline
\end{tabular}

extrusa samples from oesophageal-fistulated sheep grazing the same plot are shown in Table 5 (GR Iason, unpublished results). It is clear that, in this study, differences between the two sample types were negligible.

The fact that faecal alkanes can also be used to determine diet composition may entirely remove the need to use oesophageal-fistulated animals; this could well be the greatest advantage of the alkane technique. In such cases the estimate of diet composition provides estimates of the alkane concentrations of the whole diet, with which intake can then be estimated.

Although Mayes et al. (1986a) were unable to find evidence of systematic diurnal variation in the faecal concentration ratios of dosed and herbage alkanes, such variation was observed in later studies. In dairy cattle, Dillon \& Stakelum (1989) showed that the dosed alkane $\left(\mathrm{C}_{32}\right)$ was responsible for the diurnal variation. Thus, as with $\mathrm{Cr}_{2} \mathrm{O}_{3}$, the method of alkane dosing may influence the degree of diurnal variation in the faecal alkane ratio. Various carrier matrices for dosed alkanes have been tested, including shredded paper, powdered cellulose, paper stoppers and aqueous suspensions. The relative attributes of these have been discussed recently by Mayes \& Duncan (1999). Alkane controlled-release devices have been developed to deliver even-chain alkanes for determining intake. They are designed to deliver alkane over a period of $20 \mathrm{~d}$ after insertion; faeces can be sampled after the first $7 \mathrm{~d}$. The devices have been shown to be reliable (Table 6) and are now commercially available in sizes that allow intake estimation in adult sheep, and growing and adult cattle (Captec Alkane ${ }^{\mathrm{TM}}$, Captec (N.Z.) Ltd, Auckland, New Zealand).

Analogous to the use of a single dose of an external marker to estimate faecal output, dietary intake can be estimated using $n$-alkanes with the dosed alkane given as a single administration. Intake is calculated in the same way as for daily dosing except that the ratio of areas under the faecal excretion curves for the two alkane markers is used. This method has been validated in laboratory rabbits (Letso, 1996). It has not been tested in ruminants, but a modification of this procedure, developed for estimating both intake and diet composition over

Table 6. Effectiveness of controlled-release devices (CRD) as a means of administering $\mathrm{C}_{32}$-alkane for the purpose of estimation of intake in sheep: discrepancies between actual intake of grass dry matter (DM) and intakes estimated using $\mathrm{C}_{32^{-}}$and $\mathrm{C}_{33^{-}}$-alkanes as markers

\begin{tabular}{|c|c|c|c|c|c|}
\hline \multirow[b]{2}{*}{ Reference } & \multirow{2}{*}{$\begin{array}{l}\text { Days after CRD } \\
\text { insertion }\end{array}$} & \multirow[b]{2}{*}{$n$} & \multirow{2}{*}{$\begin{array}{c}\text { Actual intake } \\
\text { mean }(g \text { DM/d) }\end{array}$} & \multicolumn{2}{|c|}{ *Discrepancy (g DM/d) } \\
\hline & & & & Mean & SE \\
\hline $\begin{array}{l}\text { Mayes et al. (1991) } \\
\text { Molle et al. (1998) }\end{array}$ & $\begin{array}{c}6-13 \\
7-11 \dagger \\
14-18 \\
21-25\end{array}$ & $\begin{array}{r}24 \\
5 \\
5 \\
5\end{array}$ & $\begin{array}{l}913 \cdot 5 \\
666 \\
717 \\
690\end{array}$ & $\begin{array}{c}+0.2 \\
+18 \\
-45 \\
-1\end{array}$ & $\begin{array}{l}16.50 \\
21.0 \\
15.9 \\
82.3\end{array}$ \\
\hline
\end{tabular}

* Actual DM intake minus DM intake estimated using alkane markers.

$\dagger$ Same sheep and CRD used in all three measurement periods. 
a period of 6-48 h, has been evaluated in sheep (Duncan et al. 1999); in such an approach, not only the dosed alkanes but also dietary alkanes over the short grazing period (present at much higher concentrations than in the feed given before and after the experimental period) were considered as being 'single doses'.

\section{The use of marker- and digestibility-based methods for estimating intake and dietary composition in free-ranging non-ruminant animals}

Few attempts have been made to measure intake in free-ranging non-ruminant herbivores, compared with domestic ruminants, though theoretically the majority of available techniques could be used. However with a substantial increase in recent years in the outdoor rearing of pigs (considered herbivores for the purpose of this review) and with a growing interest in horse nutrition, there is a greater need to be able to determine intake of grazed vegetation by these animals.

Conventional faecal markers have been used in pigs and horses, primarily for estimation of diet digestibility and faecal output (for example see Moughan et al. 1991; Jagger et al. 1992; Todd et al. 1995) in housed animals. However, the concept of using an in vitro digestibility estimate for the purpose of intake determination in such animals has not been adopted. This is despite the fact that a number of in vitro methods have been developed, relevant to both pigs (Moughan, 1999) and horses (Miraglia \& Tisserand, 1985; Lowman et al. 1999), to predict in vivo digestibility for the purpose of giving an indication of the nutritive value of the diet.

By contrast, the alkane marker technique for measuring intake has been tested in nonruminants. Faecal alkane recovery measurements and intake validation trials have been carried out in horses (Dove \& Mayes, 1996; O'Keefe \& McMeniman, 1998). The alkane method was shown to be reliable, but unlike results in ruminants, the faecal recoveries of both dietary and dosed alkanes did not decrease with decreasing C-chain length. Gannon (1996) demonstrated that the alkane marker gave reliable intake estimates in pigs. However, Wilson et al. (1999) observed differences between the faecal recoveries of the natural $\left(\mathrm{C}_{33}\right)$ and dosed $\left(\mathrm{C}_{32}\right)$ alkanes, which led to bias in resultant intake estimates. Despite the obvious need to investigate discrepancies in validation results between different studies, estimates of herbage intake by freeranging pigs have provided a useful insight into their nutrient supply (Gannon, 1996; MG Rivera Ferre, SA Edwards, RW Mayes, I Riddoch and D Hovell, unpublished results). Letso (1996) obtained reliable intake estimates in laboratory rabbits fed on pelleted grass meal, when the dosed alkane was administered either daily or as a single dose. These studies indicate that the alkane method can be used to estimate dietary intake in a range of non-ruminants and could probably be applicable to many other species. The method has recently been used in freeranging elephants (IJ Gordon, personal communication).

Diet composition in wild non-ruminants has been studied by examination of stomach contents and faeces sampling using microhistological techniques (Wallace-Drees et al. 1986; Cornelis et al. 1999). The limitations of this technique are generally the same as those in ruminants. Plant-wax alkanes have been used as faecal markers to determine diet composition. The relative faecal recoveries of individual alkanes are similar in pigs (Gannon, 1996; Wilson, 1998), horses (Dove \& Mayes, 1996) and hares (Hulbert, 1993), which suggests that in nonruminants, in contrast to ruminants, recovery corrections are not required (Fig. 3). Using alkanes as diet composition markers, Hulbert (1993) characterized seasonal changes in the diet of mountain hares in the Scottish highlands. Alkanes have also been used to estimate diet composition in Australian marsupial species (for example see Woolnough, 1998). 


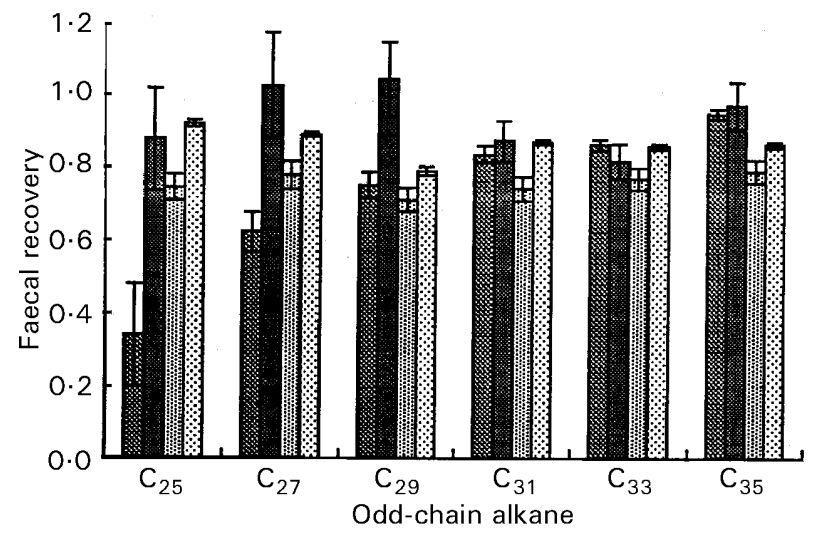

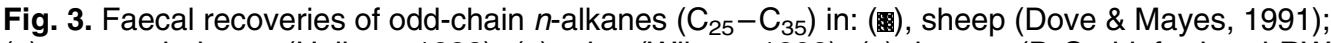
(四), mountain hares (Hulbert, 1993); (国), pigs (Wilson, 1998); (园), horses (D Cuddeford and RW Mayes, unpublished results). Values are means with standard errors represented by vertical bars.

\section{Other animal-based methods of measuring intake}

\section{Estimating intake and diet composition from behavioural observations}

At its simplest, the behaviour of a foraging herbivore can be directly observed and its intake rate obtained from the time spent consuming a food resource and/or the number of bites taken per unit time on that resource. Where there are several food types on offer, such as different vegetation patches or browsable tree species, this approach could be applied to obtain a measure of diet composition. A logical means of obtaining an estimate of intake from behavioural measurement is:

$$
\begin{aligned}
\text { intake }(\mathrm{kg} \mathrm{DM} / \mathrm{d})= & \text { bite rate during feeding }(\text { bites } / \mathrm{h}) \times \text { feeding time }(\mathrm{h} / \mathrm{d}) \\
& \times \text { bite size }(\mathrm{kg} \mathrm{DM} / \text { bite }) .
\end{aligned}
$$

Such estimates of intake are likely to be crude for the following reasons: (1) the size of a 'bite' can vary greatly; (2) the observation period is likely to be relatively short (usually less than a day); (3) it may be difficult to make clear observations without disturbing the animals.

Because a herbivore may use different ingestive strategies for different plant species and plant parts, bite sizes are likely to vary greatly between the types of material eaten. Different techniques for measuring bite size may be required for different types of plant material. A simple 'plantbased' approach has been adopted with some success for browsing animals where the bite size can be assessed as the diameter of a bitten tree twig (Vivås \& Sæther, 1987) or the distance from the end of the twig that leaves have been stripped. Bite size can be determined by measuring the relevant amount of material removed by an operator from similar intact twigs. Although relatively large numbers of measurements are required, the variability of bite size can be assessed.

More widely used animal-based methods, particularly for animals grazing high-quality swards, involve the use of oesophageal-fistulated animals or measurement of short-term liveweight change. When oesophageal-fistulated animals are used, the amounts of extrusa collected and the number of bites are monitored. Both the type of ingested plant material and bite size must be representative of the intact test animals, and there must be no loss of ingested material through swallowing or spillage. For determination of bite size by short-term weight change, 
animals are fitted with harnesses for total collection of excreta and the total number of bites taken over a grazing period of $1-2 \mathrm{~h}$ is recorded (Penning \& Hooper, 1985). The animals are weighed immediately before and after the grazing period and corrections made for evaporative $\mathrm{H}_{2} \mathrm{O}$ loss and production of $\mathrm{CO}_{2}$ and $\mathrm{CH}_{4}$. Such weight loss, the insensible weight loss, has been determined by preventing the same animals from feeding by penning outdoors, for a similar duration before or after the grazing period. Although the availability of highly accurate weighing machines has improved precision, several factors could still limit the accuracy of measurements. Estimates of insensible weight loss may not be strictly valid since there could be differences in metabolic rate, gut fill and fermentation rate between feeding and penned animals. However, such measurements are easier to make and probably less prone to error than a more direct alternative approach, such as using tracer techniques to measure $\mathrm{H}_{2} \mathrm{O}$ turnover and $\mathrm{CO}_{2}$ production rate. Furthermore the weight-change method could be unreliable in rainy or misty conditions when the animal's coat can take up water. Even dew on the vegetation may be a problem, as the herbage DM content may be extremely variable under such conditions.

Both of these animal-based methods give mean estimates of bite size representative of a short period of grazing. Gibb et al. (1998) showed that bite size can change throughout the day, and this needs to be considered when using behavioural techniques to obtain intake estimates which represent daily or longer-term values. Despite these reservations, it has been shown in goats that intake estimates obtained using short-term weight change to determine bite size and direct manual observation over short periods to measure bite rate were very similar to intakes obtained using $\mathrm{C}_{32}$ and $\mathrm{C}_{33}$ alkanes as markers (Sendalo, 1995). Whilst such work does not validate either intake-measurement technique, it does suggest that both approaches can give reasonable estimates of the true intakes.

In theory, the above limitations of using direct behavioural observations to determine intake can be overcome: continuous manual observations could be made over a period of many days taking care to minimize disturbance. It is largely because of the logistical impracticality of such an approach that automated devices to monitor foraging behaviour have been developed. Photographic and video-recording equipment have been widely used to observe animal locations and make simple behavioural observations about the animal (e.g. grazing, walking or lying down). However, the resolution of such techniques is such that it is rarely possible to measure bite rate or, unless the vegetation type is present in discrete patches, the plant species or plant part from which individual bites were taken.

Alternative approaches in which the animals carry the monitoring equipment have been developed over many years. A simple device for recording grazing activity in sheep or cattle on short swards, in terms of the lowering of the head to represent grazing, has been available for many years (Vibracorder, Kienzle Apparate GmbH, Villingen, Germany; Allden, 1962); tilt switches have also been used. Since such devices are not capable of recording individual bites, equipment has been developed to record jaw movements by various means, including pneumatic balloons, strain gauges and, more recently, a C-packed rubber tube which, upon stretching, exhibits a change in its electrical resistance (Penning, 1983). Microphones to monitor the sound of jaw activities have also been used (Laca et al. 1994). The outputs from these transducers have been recorded as analogue signals on magnetic tape, or digitally to a fixed computer via a radio link or a data recorder mounted on the animal. These devices have allowed the ingestive behaviour of animals to be monitored continuously for periods of $24 \mathrm{~h}$ or more. Since jaw movements are not restricted to biting activity, there is a need to distinguish biting, chewing and, in the case of ruminants, rumination activities from the recordings. The tedium of making such interpretations has recently been removed by the development of 
computer software to automate the process. Rutter (1999) has recently reviewed automated techniques for monitoring ingestive behaviour.

Intake methods using automated monitoring equipment have generally been restricted to domestic livestock grazing high-quality pastures. Under such conditions, for example dairy cattle on perennial ryegrass swards, this approach has been effective in improving understanding of the effects of pasture-management strategies on animal performance. For the equipment to be used in a wider range of scenarios, such as in forest and rangeland environments, further development work is required. As the ingestive behaviour of a herbivore will vary according to the nature of the plant being harvested, the interpretative software for discriminating jaw activities may need much revision to cope with animals in heterogeneous environments. Existing equipment is probably too fragile to allow reliable data acquisition in many semi-natural environments. However, for a number of years, devices using radio transmitters or global positioning systems, developed to locate wild animals, have been highly successful. With modern electronic technology it is feasible to make more robust equipment for monitoring ingestive behaviour and to increase the number of measurement variables, their accuracy and their duration (Rutter, 1999). It is unfortunate that, for reasons of cost and logistics, the number of animals which could be simultaneously fitted with monitoring equipment is always likely to be limited.

\section{Intake estimates based on turnover rates}

Dietary intake has been estimated in free-ranging ruminants from determination of their water turnover rates by sequential blood sampling following a single injection of ${ }^{3} \mathrm{H}_{2} \mathrm{O}$ (Benjamin et al. 1975; Silanikove et al. 1987). Under arid conditions when no drinking water was available, $\mathrm{H}_{2} \mathrm{O}$ turnover rate was assumed to be the same as $\mathrm{H}_{2} \mathrm{O}$ intake and DM intake could be calculated from knowledge of the DM content of the diet. The method can also be used when the intake of drinking water is known. Under less arid conditions, many herbivores can be expected to meet their requirements for $\mathrm{H}_{2} \mathrm{O}$ entirely from the diet and so, in theory, the $\mathrm{H}_{2} \mathrm{O}$ turnover method could be used to determine intake. However, there is potential for dietary moisture content to vary considerably and collecting representative samples of vegetation could be difficult, especially with the incidence of rain or heavy dew. Potential restrictions on the use of ${ }^{3} \mathrm{H}_{2} \mathrm{O}$, due to its radioactivity, could be avoided by using ${ }^{2} \mathrm{H}_{2} \mathrm{O}$ instead (Rogers et al. 1985). Despite the number of estimates of energy expenditure made in free-ranging herbivores by the 'double-labelled water' method, which involves measuring the turnover rates of ${ }^{2} \mathrm{H}$ and ${ }^{18} \mathrm{O}$ in the body- $\mathrm{H}_{2} \mathrm{O}$ pool (Nagy et al. 1999), the potential to use the ${ }^{2} \mathrm{H}$ data to estimate dietary intake has not been exploited.

A similar approach, but without the problems associated with free $\mathrm{H}_{2} \mathrm{O}$ consumption and variation in dietary moisture content, is to estimate intake from the turnover rate of $\mathrm{Na}$ in the animal and the dietary $\mathrm{Na}$ content (Green, 1978). Na from the diet is completely absorbable from the gut (Farley \& Robbins, 1997) and thus equilibrates with the body-Na pool. Naturnover rate can be determined by measuring the radioactivity of blood plasma or serum following a single injection of ${ }^{22} \mathrm{Na}$ as a tracer. This method has been quite widely used to measure dietary intake in carnivores but its use in herbivores has been limited; the method has been tested in rabbits (Green \& Dinsmore, 1978), reindeer (Staaland et al. 1982) and cattle (Silanikove et al. 1987). Its accuracy is higher for diets of relatively high Na content (Farley \& Robbins, 1997); unfortunately, the diets of most herbivores have relatively low Na levels. As with ${ }^{3} \mathrm{H}_{2} \mathrm{O}$, the use of ${ }^{22} \mathrm{Na}$ as a radioactive tracer may be restricted for legal and safety reasons. 
${ }^{3} \mathrm{H}_{2} \mathrm{O}$ and ${ }^{2} \mathrm{H}_{2} \mathrm{O}$ have also been used to obtain estimates of milk intake both in domestic species (for example see Dove, 1988) and wild herbivores (for example see Krockenberger et al. 1998). By concurrently administering ${ }^{3} \mathrm{H}_{2} \mathrm{O}$ to the dam and ${ }^{2} \mathrm{H}_{2} \mathrm{O}$ to the offspring, milk intake can be estimated from the total body- $\mathrm{H}_{2} \mathrm{O}$ turnover of the offspring and the proportion of this coming from milk (Holleman et al. 1975; Dove, 1988). The difference between the two represents mainly the intake of $\mathrm{H}_{2} \mathrm{O}$ in vegetation and drinking water. Krockenberger $e$ a al. (1998) recently estimated the foliage intake of young koalas (Phascolarctus cinereus) from the 'non-milk' component of their total $\mathrm{H}_{2} \mathrm{O}$ turnover. This requires an estimate of the foliage DM content and assumes that the free $\mathrm{H}_{2} \mathrm{O}$ intake is negligible. In koalas, this assumption is reasonable (Krockenberger et al. 1998).

\section{Estimating intake of components other than grazed vegetation}

In certain circumstances, free-ranging herbivores may consume components additional to grazed or browsed vegetation, such as dietary feed supplements, milk in young herbivores, and ingestion of soil, both intentional or circumstantial. These can have a large effect on the total intake of nutrients and other substances. Thus there may be a need to determine concurrently the intake of both vegetation and the additional component.

\section{Estimating supplement intake}

In agricultural production systems, supplementary feeding is commonplace and a knowledge of the supplement intake of individual grazing animals would greatly facilitate progress in understanding the response to supplements. The possibility of associative effects of cellulosic (herbage) and starchy (cereal supplement) diet components on digestibility has been mentioned earlier. However, the effects of feeding of grain supplements on the voluntary intake of herbage (substitution) are usually larger than those on digestion itself (Dixon \& Stockdale, 1999), implying that the substitution effect relates to factors in addition to the effect of the supplement on the rate of digestion of the herbage. This highlights the need for methods of measuring intake of both vegetation and supplement that do not depend upon estimates of in vitro digestibility, but which accommodate the level of whole-diet digestibility occurring in individual animals, whatever their supplement intake.

Methods for estimating supplement intake have been reviewed recently by McLennan (1999). Most have been based on the concept of labelling the supplement with a marker and, depending on the type of marker, monitoring its concentration in either faeces, blood plasma or body $\mathrm{H}_{2} \mathrm{O}$. The size of the pool in which the marker is distributed must also be quantified in some way. A collation of some published marker-based estimates of supplement intake is given in Table 7.

Accurate estimates of supplement intake in penned animals were obtained with $\mathrm{Cr}_{2} \mathrm{O}_{3}$ (Dove \& Coombe, 1992; Table 7), while Curtis et al. (1994) found that in grazing animals consuming lupin seed from a self-feeder, the summed individual intakes were within $5 \%$ of the weight of lupins added to the feeder. By contrast, Dove \& Oliván (1998) found that when $\mathrm{C}_{38^{-}}$ alkane was sprayed on sunflower meal as a marker, supplement intake was significantly underestimated (Table 7), because of the low faecal recovery of the $\mathrm{C}_{38}$-alkane. In free-ranging animals faecal output can be determined using methods described earlier, such as total col- 
Table 7. Collation of some published estimates of the accuracy of marker-based estimates of supplement intake in sheep

\begin{tabular}{|c|c|c|c|c|c|c|}
\hline \multirow[b]{2}{*}{ Reference } & \multirow[b]{2}{*}{ Marker } & \multirow[b]{2}{*}{ Sample* } & \multicolumn{3}{|c|}{ Regression $\uparrow, y=m x+b$} & \multirow{2}{*}{$\begin{array}{l}\text { Regression differs } \\
\text { from } y=x \text { ? }\end{array}$} \\
\hline & & & $\mathrm{m}$ & $b$ & $r^{2}$ & \\
\hline $\begin{array}{l}\text { Dove \& Coombe (1992) } \\
\text { Dove \& Oliván (1998) } \\
\text { Dove \& Oliván (1998) } \\
\text { Kahn (1994) } \\
\text { Juwarini et al. (1981)§ } \\
\text { Dove et al. (1995) } \\
\text { Dove (1984) } \\
\text { Dove \& Coombe (1992) }\end{array}$ & $\begin{array}{l}\mathrm{Cr}_{2} \mathrm{O}_{3} \\
\mathrm{C}_{38} \text { alkane } \\
\text { Alkane mix: } \\
\text { Lithium } \\
{ }^{3} \mathrm{H}_{2} \mathrm{O} \\
{ }^{3} \mathrm{H}_{2} \mathrm{O} \\
\left.{ }^{3} \mathrm{H}\right] \text { gypsum } \\
\left.{ }^{3} \mathrm{H}\right] \text { gypsum }\end{array}$ & $\begin{array}{l}\text { Faeces } \\
\text { Faeces } \\
\text { Faeces } \\
\text { Plasma } \\
\text { Body water } \\
\text { Body water } \\
\text { Body water } \\
\text { Body water }\end{array}$ & $\begin{array}{l}1.05 \\
0.84 \\
0.99 \\
1.00 \\
0.97 \\
1.07 \\
1.07 \\
0.97\end{array}$ & $\begin{array}{r}-4.50 \\
-7.37 \\
10.66 \\
0.03 \\
10.81 \\
-12.28 \\
-19.58 \\
8.86\end{array}$ & $\begin{array}{l}0.963 \\
0.989 \\
0.991 \\
0.98 \\
0.990 \\
0.957 \\
0.973 \\
0.997\end{array}$ & $\begin{array}{l}\text { No } \\
\text { Yes } \\
\text { No } \\
\text { No } \\
\text { No } \\
\text { No } \\
\text { No } \\
\text { No }\end{array}$ \\
\hline
\end{tabular}

* Sample in which marker actually analysed.

$\dagger y=$ supplement intake estimated using marker; $x=$ known supplement intake. See original publications for standard errors of regression variables.

Supplement intake estimated from estimate of supplement proportion in total intake.

$\S$ Calculated from data in Juwarini et al. (1981).

lections with bags and harnesses or from dosing with another marker such as $\mathrm{C}_{36}$-alkane (Dove \& Oliván, 1998).

An alternative is to use markers which can be monitored in the blood. Juwarini et al. (1981) labelled whole grain with ${ }^{3} \mathrm{H}_{2} \mathrm{O}$, by soaking oven-dried wheat in ${ }^{3} \mathrm{H}_{2} \mathrm{O}$ and allowing it to air-dry. Dove et al. (1995) used this method with oat grain and, in both studies, measurement of the accumulation of ${ }^{3} \mathrm{H}$ in the body- $\mathrm{H}_{2} \mathrm{O}$ pool resulted in accurate estimates of supplement intake (Table 7). To prevent evaporative losses of ${ }^{3} \mathrm{H}_{2} \mathrm{O}$, Dove (1984) mixed plaster of Paris with ${ }^{3} \mathrm{H}_{2} \mathrm{O}$ to form a stable marker $\left(\left[{ }^{3} \mathrm{H}\right]\right.$ gypsum; $\left.\mathrm{CaSO}_{4} \cdot 2 \mathrm{H}_{2} \mathrm{O}\right)$ which was then incorporated into the supplement $(10 \mathrm{~g} / \mathrm{kg})$. This proved an excellent marker for estimating supplement intake (see Table 7). Like the method of Juwarini et al. (1981), it requires estimates of ${ }^{3} \mathrm{H}_{2} \mathrm{O}$ dilution space and $\mathrm{H}_{2} \mathrm{O}$ turnover rate in the animals (for details see Dove, 1984). In theory, ${ }^{3} \mathrm{H}_{2} \mathrm{O}$ could be replaced by non-radioactive ${ }^{2} \mathrm{H}_{2} \mathrm{O}$.

Suharyono et al. (1991) and Kahn (1994) determined supplement intake by monitoring Li levels in blood plasma $4-14 \mathrm{~h}$ after offering animals a single feed of supplement containing $\mathrm{LiCl}$. Having assumed that Li distribution volume was proportional to live weight, the product (Li concentration $\times$ live weight) for each animal was expressed as a proportion of the sum of these products across all animals; this gave an estimate of the proportion of the total supplement offered which was consumed by each animal. Although the method gives accurate estimates of supplement intake (see Table 7), care is needed to avoid feed aversions due to high dietary levels of $\mathrm{LiCl}$ (Burritt \& Provenza, 1989). To avoid this, Kahn (1994) suggested that supplement labelling should aim to result in daily intakes of about $50 \mathrm{mg} \mathrm{LiCl} / \mathrm{kg}$ live weight. Another possible disadvantage of this approach is that, in more extensive feeding situations, a single day may not be sufficient time to obtain an estimate of the supplement intake for all individual animals.

Another method of estimating supplement intake is to consider the supplement as one component of a mixed diet and to determine the diet composition from the patterns of $n$-alkane in the faeces and in the dietary components, using the method described earlier. Intake of both basal diet and supplement can then be determined from the same analysis by reference to dosed $\mathrm{C}_{32}$-alkane. To use this approach, the supplement must have alkanes at reasonable levels with a profile that differs from that of the basal diet. This is so with forage-based supplements (e.g. hay, silage) and some grains such as wheat or oats. Hameleers \& Mayes (1998b) determined intakes of grass silage and grazed herbage in cattle by this method. Supplements which have no plant wax, such as legume grains and extracted oilseed meals, could be sprayed with alkane 
mixtures. Dove \& Oliván (1998) sprayed sunflower meal with beeswax, which has high levels of alkanes. This allowed the proportions of supplement and the roughage component (chaff) in the diet to be estimated. By reference to dosed alkanes, derived total and supplement intakes agreed very closely with known values (Dove \& Oliván, 1998; Table 7).

\section{Estimating soil intake}

As mentioned earlier, free-ranging herbivores often ingest appreciable quantities of soil, either by choice or inadvertently; this may provide useful quantities of both trace elements and macro-elements (Dewes, 1996; Grace et al. 1996). Furthermore, many environmental pollutants, including radionuclides, heavy metals and organic compounds, accumulate in soil but their uptake by plants is limited (Jones, 1991; Webber et al. 1994). In these circumstances the ingestion of soil can be a major route of transfer to the animal (Beresford \& Howard, 1991; Abrahams \& Thornton, 1994).

One method of estimating inadvertent soil intake is to determine the degree of contamination of vegetation with soil and to measure vegetation intake. Another method is to estimate the output of soil in faeces. In the first method, great care is necessary in obtaining a sample of vegetation which is representative in terms of soil contamination. Various methods have been used to assess the soil content of a vegetation sample (for review see Hinton, 1992). Most have used elements which are present in the soil but are not taken up by plants; the degree of soil contamination can be estimated from the concentrations of the marker element in the vegetation sample and a representative sample of soil. The most widely used element has been $\mathrm{Ti}$, but others, such as $\mathrm{Sc}$, have also been employed. In comparative studies, Hinton et al. (1995) observed that differences in estimates of soil contamination obtained from different markers were due to differences in the distribution of the markers across different soil particle sizes. Thus soil particles adherent to vegetation may not have the same marker content as that of a bulk soil sample. It is possible that a different approach to measure soil contamination of vegetation, such as careful washing (Hinton, 1992), may be more accurate.

Total soil intake (including intentional ingestion) can be determined from the faecal concentration of an indigestible component, which is present in soil but not in vegetation. Ti has been the most popular marker (for example see Mayland et al. 1975) since $\mathrm{TiO}_{2}$ is completely recovered in faeces (for example see Jagger et al. 1992). Acid-insoluble ash has also been used but has tended to overestimate faecal soil content, due to the presence of silica (the major component of acid-insoluble ash) in plant material (Mayland et al. 1975). To quantify the amount of soil excreted in faeces an estimate of total faecal output is required. Using Ti and dosed alkanes it has recently been shown that, in adult pigs at pasture, soil can comprise up to $50 \%$ of faecal DM (MG Rivera Ferre, SA Edwards, RW Mayes, I Riddoch and D Hovell, unpublished results). No validation studies have been carried out in which faecal outputs of soil have been compared with known intakes. Thus, even if the Ti method gives reliable estimates of excretion rate of soil mineral matter, it is not certain whether such values give a true indication of soil intake. Faecal recoveries of soil OM are not known and it is possible that the amounts of soil residing in the gut may vary over a considerable period.

\section{Estimating intake of digestible nutrients and digestion end-products}

In carrying out nutritional studies with free-ranging herbivores there are many instances in which knowledge of the intake of absorbable nutrients is more useful than that of the gross amounts ingested. For some nutrients, the estimation of digestibility in conjunction with an 
estimate of total intake would suffice but, for others, different methods would need to be employed.

As mentioned earlier, some of the methods for determining intake require estimates of whole-diet digestibility. Such methods can thus provide estimates of digestible DM or digestible OM intake; the latter is particularly useful as it closely approximates digestible energy intake. As mentioned earlier, plant-wax alkanes can be used as internal markers to provide digestibility estimates, but require correction for incomplete recovery (Mayes \& Lamb, 1984); uncertainty in prediction of such recoveries may limit the accuracy of results.

An alternative method is to estimate digestibility in free-ranging animals from a knowledge of intake and faecal output, the latter being measured by total collection or an indigestible external marker. If intake is estimated using dosed $\mathrm{C}_{32}$-and dietary $\mathrm{C}_{33}$-alkanes as markers, the dosed $\mathrm{C}_{32}$-alkane could, at the same time, provide an estimate of faecal output, but requires correction for incomplete recovery. A more satisfactory marker, because it has a faecal recovery of at least $95 \%$, is dosed $\mathrm{C}_{36}$-alkane (Mayes et al. 1986b; Dove \& Oliván, 1998). This alkane has been incorporated into the commercially available alkane controlled-release device for the express purpose of permitting estimates of faecal output and hence digestibility.

In ruminants, the influence of diet and rumen microbes on the supply of absorbable energy and protein cannot be adequately assessed by merely estimating the digestibilities of dietary $\mathrm{OM}$ and protein. The fermentation processes in the ruminant foregut have been quantified in housed animals, surgically prepared with cannulas in the rumen and abomasum or duodenum, by using intraruminally infused digesta-flow markers, such as CrEDTA and Ru-phenanthroline complexes, and microbial markers (e.g. $\left[{ }^{35} \mathrm{~S}\right]$ sulfate). The development of portable pumps for infusion of markers (for example see Corbett et al. 1976) and automatic digesta sampling equipment (Evans et al. 1981) extended such measurements to grazing animals (for example see Beever et al. 1986; Cruickshank et al. 1992). The natural alkanes in the diet have potential as markers for determining digesta flow through the duodenum, as no losses occur in the forestomachs and they remain attached to digesta particles (Mayes et al. 1988; Samaniego, 1996). With associated intake estimates they allow estimations of digesta flow to be made without the need for rumen cannulation or infusion equipment. However, dietary alkanes have not yet been used to measure digesta flow in free-ranging ruminants.

The need for surgical intervention to quantify rumen digestion of $\mathrm{OM}$ and microbial protein represents a major disadvantage of the approach. Not only are there ethical concerns regarding the health and well-being of surgically prepared animals but also their maintenance is labour intensive. However, microbial protein supply can be estimated without the need for cannulated animals by measuring the urinary excretion rate of purine derivatives (predominantly allantoin). These compounds originate primarily from the nucleic acid present in microbial material which, after leaving the reticulorumen, is digested and absorbed in the small intestine. Microbial protein supply can be estimated from relationships previously obtained between microbial protein leaving the reticulorumen and the urinary excretion rate of purine derivatives. Whilst this method could be used in free-ranging ruminants, it is necessary to collect urine samples and measure urinary output (Mayes et al. 1995).

Although equipment has been developed for the direct measurement of output and sampling of urine in free-ranging sheep (for example see Chambers et al. 1976) and cattle (for example see Betteridge \& Andrewes, 1986), none has been entirely successful. Markers such as inulin, $p$-aminohippuric acid and CrEDTA could be used to estimate urinary output, since they are quantitatively excreted in the urine following intravenous infusion. This method has been tested in man (Bingham \& Cummings, 1983) and caged mink (Wamberg et al. 1996) and, in theory, could be used in herbivores. Further simplification of the measurement of urine output 
would be possible if markers could be administered orally; their absorption from the gut and subsequent excretion would have to be quantitative. Experimental evidence suggests that salicyclic acid (Pagella, 1998) and orcinol (Martin et al. 1983) may be suitable markers, provided that the dose rate is too low to affect the animals physiologically. Without the need for dosing, creatinine has been used as an endogenous urinary marker to give an indication of urinary output. Although urinary creatinine output is relatively constant within individuals, it may not be sufficiently predictable to allow accurate estimates of urinary excretion rates (Faichney et al. 1998).

For a number of nutrients, especially trace and macro minerals, the extent of their endogenous excretion in faeces is sufficiently high that the apparent digestibility (absorption coefficient) gives a poor indication of transfer across the gut wall. This also applies to a range of pollutant radionuclides and heavy metals. With the availability of isotopic tracers it is possible to quantify endogenous faecal excretion of a range of essential mineral elements and pollutants, and hence to determine the extent of 'true' absorption. One approach, considering $\mathrm{Ca}$ for example, is to administer ${ }^{45} \mathrm{Ca}$ intravenously at the same time as conducting Ca balance measurements (for example see Martz et al. 1999); this allows the endogenous faecal excretion of $\mathrm{Ca}$ to be estimated. Various modifications of this approach to quantify the true absorption of radio-labelled Cs have been discussed by Mayes et al. (1996). The methodology now exists for determining the intakes of 'truly absorbable' elements by free-ranging animals. Howard et al. (1993) attempted to estimate the intakes of truly absorbable ${ }^{137} \mathrm{Cs}$ and ${ }^{90} \mathrm{Sr}$ in dairy cattle grazing contaminated pasture close to the Chernobyl nuclear power plant. The tracer radionuclides ${ }^{134} \mathrm{Cs}$ and ${ }^{85} \mathrm{Sr}$ were administered intravenously by portable infusion pump; herbage intakes and faecal outputs were determined using alkanes as markers. The relative outputs of the tracer radionuclides in milk and faeces enabled the endogenous faecal excretion and hence intakes of truly absorbable ${ }^{137} \mathrm{Cs}$ and ${ }^{90} \mathrm{Sr}$ to be determined.

\section{Possible future directions in the development of methodologies for estimating intake in free-ranging herbivores}

Recent technological advances in the areas of microelectronics, data processing and analytical chemistry offer considerable potential for improving our ability to estimate intake in freeranging animals. Aspects that we consider as likely key areas are described below:

(1) developments in the use of markers: compared with the substances potentially available for use as markers, very few have been exploited for this purpose. In particular, the concept of using plant compounds as markers for characterizing diet composition is relatively new. With modern methods of chemical analysis the scope for using a wide range of plant compounds as diet composition markers is considerable. It should soon be possible to make accurate measurements of diet composition in conditions where animals have the opportunity of selecting highly complex diets.

There is also potential to exploit, as markers, compounds that are excreted in urine. In addition to the use of urinary allantoin to predict microbial protein synthesis, hippuric acid has the potential of being used to study interactions between the fermentation of starch and fibre, since much of it originates from the rumen digestion of lignocellulose (Mayes et al. 1995). Urinary metabolites may be used to identify plant species eaten by herbivores, since breakdown products of many plant secondary compounds appear in the urine;

(2) combination of different measurement techniques: the ability to estimate nutrient intake in free-ranging herbivores could be much improved through the concurrent use of different 
methodologies. Examples have already been mentioned but there are many more. For instance, Garcia et al. (1999) estimated intakes of maize silage and pasture grass in grazing cattle using a combination of the $\delta^{13} \mathrm{C}$ and alkane techniques. Using faecal and urinary markers together allows both digestible intake and microbial protein synthesis rate to be determined simultaneously, thus giving an insight into protein-energy relationships in the rumen. Furthermore, the estimation of urinary output, dietary intake and faecal output would enable various nutrient (e.g. $\mathrm{N}$ and minerals) balance studies to be conducted in freeranging animals (Mayes et al. 1995). The use of marker methods together with behavioural monitoring techniques can also be exploited. For example, global positioning system techniques can be used to monitor both the location of an animal and when the animal occupied that location. This information not only can be used to give an indication of the vegetation ingested by the animal but also can indicate the location of faeces and the time that defaecation occurred;

(3) intake measurements in herbivores inhabiting semi-natural environments: through many of the advances described above it is likely that much progress will be made in the ability to determine intake in animals, particularly wild herbivores, foraging within a range of extensive habitats. In conjunction with global positioning systems monitoring, the development of controlled-release devices to administer markers over a sustained period offers the opportunity not only to estimate intake and faecal output but also to monitor individual ruminants within a group; a unique combination of marker administered via a controlledrelease device to each animal would enable faeces to be identified. Although controlledrelease devices are not presently available for non-ruminants, it may be possible to use single doses of exogenous markers to identify faeces and estimate intake.

Both faeces and urine (samples retained in snow) have been used to assess nutritional status in wild herbivores. Levels of $\mathrm{N}$ and diaminopimelic acid (an amino acid synthesized by bacteria in the gut) in faeces have been used to assess the nutritional status of wild deer (for example see Kucera, 1997). Urinary allantoin:creatinine and urea:creatinine ratios have been used for the same purpose (Vagnoni et al. 1996; Moen \& DelGuidice, 1997). Although, to date, these markers have been used as crude indices of nutritional status, it is possible that, in combination with intake and diet-composition data, these and similar markers could provide a means of obtaining more quantitative nutritional information, in particular about the protein and energy status of the animal;

(4) beyond mammalian herbivores: despite the title of this present review, it is likely that most of the described techniques to determine dietary composition and intake are not restricted to mammals or to herbivores. For example, limited studies have been carried out on the use of alkanes as markers in farmed fish (Gudmundsson \& Halldorsdottír, 1995), chickens (Hameleers et al. 1996) and farmed ostriches (Orr, 1998). Furthermore, it is possible that the cuticular hydrocarbons, which are abundant in insects, could be used as markers to measure intake and diet composition in insectivores, such as bats.

\section{References}

Abrahams PW \& Thornton I (1994) The contamination of agricultural land in the metalliferous province of southwest England-implications to livestock. Agriculture, Ecosystems and Environment 48, 125-137.

Akhter S, Owen E, Theodorou MK, Butler EA \& Minson DJ (1999) Bovine faeces as a source of micro-organisms for the in vitro digestibility assay of forages. Grass and Forage Science 54, 219-226.

Allden WG (1962) The herbage intake of grazing sheep in relation to pasture availability. Proceedings of the Australian Society of Animal Production 4, 163-166.

Beever DE, Losada HR, Cammell SB, Evans RJ \& Haines MJ (1986) Effect of forage species and season on nutrient digestion and supply in grazing cattle. British Journal of Nutrition 56, 209-225. 
Benjamin RW, Degen AA, Breighet A, Chen M \& Tadmor NH (1975) Estimation of food intake of sheep grazing green pasture when no free water is available. Journal of Agricultural Science 85, 403-407.

Beresford NA \& Howard BJ (1991) The importance of soil adhered to vegetation as a source of radionuclides ingested by grazing animals. Science of the Total Environment 107, 237-254.

Betteridge K \& Andrewes WGK (1986) A device for measuring and sampling urine output from free-grazing steers. Journal of Agricultural Science 106, 389-392.

Bingham S \& Cummings JH (1983) The use of 4-aminobenzoic acid as a marker to validate the completeness of $24 \mathrm{~h}$ urine collection in man. Clinical Science 64, 629-635.

Burritt EA \& Provenza FD (1989) Food aversion learning: conditioning lambs to avoid a palatable shrub (Cercocarpus montanus). Journal of Animal Science 67, 650-656.

Chambers ARM, White IR, Russel AJF \& Milne JA (1976) Instruments for sampling and measuring the volume output of urine from grazing female sheep. Medical and Biological Engineering 17, 665-670.

Coates DB, Schachenmann P \& Jones RL (1987) Reliability of extrusa samples collected from steers fistulated at the oesophagus to estimate the diet of resident animals in grazing experiments. Australian Journal of Experimental Agriculture 27, 739-745.

Comeron EA \& Peyraud JL (1993) Prediction of herbage digestibility ingested by dairy cows. Revue Argentine de Production Animale 13, 23-30.

Corbett JL, Lynch JJ \& Nichol GR (1976) A versatile peristaltic pump designed for grazing lambs. Laboratory Practice $25,458-462$.

Cornelis J, Casaer J \& Hermy M (1999) Impact of season, habitat and research techniques on diet composition of roe deer (Capreolus capreolus): a review. Journal of Zoology, London 248, 195-207.

Cruickshank GJ, Poppi DP \& Sykes AR (1992) The intake, digestion and protein-degradation of grazed herbage by early-weaned lambs. British Journal of Nutrition 68, 349-364.

Curtis KMS, Holst PJ \& Murray PJ (1994) Measuring supplement intake in the field using ytterbium as a marker. Australian Journal of Experimental Agriculture 34, 339-343.

Day JEL, Kyriazakis I \& Rogers PJ (1998) Food choice and intake: towards a unifying framework of learning and feeding motivation. Nutrition Research Reviews 11, 25-43.

Dewes HF (1996) The rate of soil ingestion by dairy cows and the effect on available copper, calcium, sodium and magnesium. New Zealand Veterinary Journal 44, 199-200.

Dillon P \& Stakelum G (1989) Herbage and dosed alkanes as a grass measurement technique for dairy cows. Irish Journal of Agricultural Research 28, 104.

Dixon RM \& Stockdale CR (1999) Associative effects between forages and grains: consequences for feed utilisation. Australian Journal of Agricultural Research 50, 757-773.

Dove H (1984) Gypsum labelled with tritiated water as a marker for estimating supplement intake by individual sheep fed in groups. Australian Journal of Experimental Agriculture and Animal Husbandry 24, 484-492.

Dove H (1988) Estimation of the intake of milk by lambs, from the turnover of deuterium- or tritium-labelled water. British Journal of Nutrition 60, 375-387.

Dove H (1992) Using the $n$-alkanes of plant cuticular wax to estimate the species composition of herbage mixtures. Australian Journal of Agricultural Research 43, 1711-1724.

Dove H (1998) Pastures and grazing animals - the interaction continues. (The 1998 Underwood Lecture). Animal Production in Australia 22, 3-13.

Dove H \& Coombe JB (1992) A comparison of methods for estimating supplement intake and diet digestibility in sheep. Proceedings of the Australian Society of Animal Production 19, 239-241.

Dove H, Freer M \& Foot JZ (2000) The nutrition of grazing ewes during pregnancy and lactation: a comparison of alkane-based and chromium/in vitro-based estimates of herbage intake. Australian Journal of Agricultural Research 51, (In the Press).

Dove H \& Mayes RW (1991) The use of plant wax alkanes as marker substances in studies of the nutrition of herbivores: a review. Australian Journal of Agricultural Research 42, 913-952.

Dove H \& Mayes RW (1996) Plant wax components: A new approach to estimating intake and diet composition in herbivores. Journal of Nutrition 126, $13-26$.

Dove H \& Mayes RW (1999) Developments in the use of plant wax markers for estimating diet selection in herbivores. In Emerging Techniques for Studying the Nutritional Status of Free-ranging Herbivores [H Dove and SW Coleman, editors]. Satellite Meeting of the Vth International Symposium on the Nutrition of Herbivores, San Antonio, Texas (CD-ROM).

Dove H, Mayes RW \& Freer M (1995) Using cuticular wax alkanes to estimate herbage intake in animals fed supplements. Annales de Zootechnie 44, 237.

Dove H \& Moore AD (1995) Using a least-squares optimisation procedure to estimate botanical composition based on the alkanes of plant cuticular wax. Australian Journal of Agricultural Research 46, 1535-1544.

Dove H \& Oliván M (1998) Using synthetic or beeswax alkanes for estimating supplement intake in sheep. Animal Production in Australia 22, 189-192.

Dove H, Wood JT, Simpson RJ, Leury BJ, Gatford KL, Siever-Kelly C \& Ciavarella TA (1999) Spray-topping annual grass pasture with glyphosate to delay loss of feeding value during summer. III. Quantitative basis of the alkanebased procedures for estimating diet selection and herbage intake by grazing sheep. Australian Journal of Agricultural Research 50, 475-485. 
Duncan AJ, Mayes RW, Lamb CS, Young SA \& Castillo I (1999) The use of naturally occurring and artificially applied $n$-alkanes as markers for estimation of short-term diet composition and intake in sheep. Journal of Agricultural Science 132, 233-246.

Evans RT, Skelton KV \& Beever DE (1981) Portable equipment for the automatic sampling of duodenal contents for housed and grazing cattle. Laboratory Practice 30, 997-1000.

Faichney GJ, Welch RJ \& Brown GH (1998) Feed intake, digestion and renal function in Merino sheep selected for higher clean fleece weight. Australian Journal of Agricultural Research 49, 107-112.

Farley SD \& Robbins CT (1997) Validation of ${ }^{22}$ sodium to estimate food intake of bears. Journal of Wildlife Management 61, 53-56.

France J, Dhanoa MS, Siddons RC, Thornley JHM \& Poppi DP (1988) Estimating the production of faeces by ruminants from faecal marker concentration curves. Journal of Theoretical Biology 135, 383-391.

Furnival EP, Corbett JL \& Inskip MW (1991a) Evaluation of controlled release devices for administration of chromium sesquioxide using fistulated grazing sheep. I. Variation in marker concentration in faeces. Australian Journal of Agricultural Research 41, 969-975.

Furnival EP, Ellis KJ \& Pickering FS (1991b) Evaluation of controlled release devices for administration of chromium sesquioxide using fistulated grazing sheep. II. Variation in rate of release from the device. Australian Journal of Agricultural Research 41, 977-986.

Galyean ML (1993) Technical note — an algebraic-method for calculating fecal output from a pulse dose of an external marker. Journal of Animal Science 71, 3466-3469.

Gannon MA (1996) The energy balance of pigs outdoors. PhD Thesis, University of Nottingham.

García SC, Holmes CW, Hodgson J \& Macdonald A (1999) The combination of the $n$-alkanes and ${ }^{13} \mathrm{C}$ methods as a new tool for estimating individual DM intakes of pasture and maize silage by grazing dairy cows. Proceedings of the New Zealand Society of Animal Production 59, 156-157.

Gibb MJ, Huckle CA \& Nuthall R (1998) Effect of time of day on grazing behaviour by lactating dairy cows. Grass and Forage Science 53, 41-46.

Grace ND \& Body DR (1981) The possible use of long-chain $\left(\mathrm{C}_{19}-\mathrm{C}_{32}\right)$ fatty acids in herbage as an indigestible faecal marker. Journal of Agricultural Science 97, 743-745.

Grace ND, Rounce JR \& Lee J (1996) Effect of soil ingestion on the storage of Se, vitamin B-12, Cu, Cd, Mn and Zn in the liver of sheep fed lucerne pellets. New Zealand Journal of Agricultural Research 39, 325-331.

Green B (1978) Estimation of food consumption in the dingo, Canis familiaris dingo, by means of ${ }^{22} \mathrm{Na}$ turnover. Ecology 59, 201-210.

Green B \& Dinsmore JD (1978) Turnover of tritiated water and ${ }^{22} \mathrm{Na}$ in captive rabbits. Journal of Mammalogy 59, $12-17$.

Gudmundsson O \& Halldorsdottír K (1995) The use of $n$-alkanes as markers for determination of intake and digestibility of fish feed. Journal of Applied Ichthyology_Zeitschrift für Angewandte Ichthyologie 11, 354-358.

Hameleers A, McNab J \& Mayes RW (1996) Use of aliphatic hydrocarbons (alkanes) as markers in nutrition studies in chickens. British Poultry Science 37, 105-106.

Hameleers A \& Mayes RW (1998a) The use of $n$-alkanes to estimate herbage intake and diet composition by dairy cows offered a perennial ryegrass/white clover mixture. Grass and Forage Science 53, 164-169.

Hameleers A \& Mayes RW (1998b) The use of $n$-alkanes to estimate supplementary grass silage intake in grazing dairy cows. Journal of Agricultural Science 131, 205-209.

Hinton TG (1992) Contamination of plants by resuspension: a review, with critique of measurement methods. Science of the Total Environment 121, 177-193.

Hinton TG, Kopp P, Ibrahim S, Bubryak I, Syomor A, Tober L \& Bell C (1995) A comparison of techniques used to estimate the amount of resuspended soil on plant surfaces. Health Physics 68, 1-9.

Hoebee SE, Dove H \& Officer DI (1998) Using plant wax alkanes to estimate species composition of sub-tropical grass mixtures. Animal Production in Australia 22, 364.

Holechek JL, Vavra M \& Pieper RD (1982) Botanical composition determination of range herbivore diets: a review. Journal of Range Management 35, 309-315.

Holleman DF, White RG \& Luick JR (1975) New isotope methods for estimating milk intake and yield. Journal of Dairy Science 58, 1814-1821.

Howard BJ, Beresford NA \& Mayes RW (1993) Final report on ECP2 studies to Commission of the European Communities (ITE Merlewood). In Transfer of Radionuclides Through the Terrestrial Environment to Agricultural Products Including Agrochemical Practices [J Melin, editor]. Stockholm: Swedish Radiation Protection Institute.

Hulbert IAR (1993) The effect of upland afforestation on the ecology of Lagomorphs with different feeding strategies. $\mathrm{PhD}$ Thesis, University of Aberdeen.

Jagger S, Wiseman J, Cole DJA \& Craigon J (1992) Evaluation of inert markers for the determination of ileal and faecal apparent digestibility values in the pig. British Journal of Nutrition 68, 729-739.

Jones KC (1991) Contaminant trends in soils and crops. Environmental Pollution 69, 311-325.

Jones RJ, Ludlow MM, Throughton JH \& Blunt CG (1979) Estimation of the proportion of $\mathrm{C}_{3}$ and $\mathrm{C}_{4}$ plant species in the diet of animals from the ratio of natural ${ }^{12} \mathrm{C}$ and ${ }^{13} \mathrm{C}$ isotopes in the faeces. Journal of Agricultural Science $\mathbf{9 2}$, $91-100$.

Juwarini E, Howard B, Siebert BD, Lynch JJ \& Elwin RL (1981) Variation in the wheat intake of individual sheep measured by the use of labelled grain: behavioural influences. Australian Journal of Experimental Agriculture and Animal Husbandry 21, 395-399. 
Kahn LP (1994) The use of lithium chloride for estimating supplement intake in grazing sheep: estimates of heritability and repeatability. Australian Journal of Agricultural Research 45, 1731-1739.

Kotb AR \& Luckey TD (1972) Markers in nutrition. Nutrition Abstracts and Reviews 42, 813-845.

Krockenberger AK, Hume ID \& Cork SJ (1998) Production of milk and nutrition of the dependent young of freeranging koalas (Phascolarctus cinereus). Physiological Zoology 71, 45-56.

Kucera TE (1997) Fecal indicators, diet and population parameters in mule deer. Journal of Wildlife Management 61 $550-560$.

Laca EA, Ungar ED \& Demment MW (1994) Mechanisms of handling time and intake rate of a large mammalian grazer. Applied Animal Behaviour Science 39, 3-19.

Langlands JP (1987) Assessing the nutrient status of herbivores. In The Nutrition of Herbivores, pp. $363-390$ [JB Hacker and JH Ternouth, editors]. Sydney: Academic Press.

Le Du YLP \& Penning PD (1982) Animal based techniques for estimating herbage intake. In Herbage Intake Handbook, pp. 37-75 [JD Leaver, editor]. Maidenhead: British Grassland Society.

Letso M (1996) A study of the use of $n$-alkanes to determine dietary intake and digestibility in grazing rabbits. MSc Thesis, University of Aberdeen.

Lowman RS, Theodorou MK, Hyslop JJ, Dhanoa MS \& Cuddeford D (1999) Evaluation of an in vitro batch culture technique for estimating the in vivo digestibility and digestible energy content of equine feeds using equine faeces as the source of microbial inoculum. Animal Feed Science and Technology 80, 11-27.

McLennan SR (1999) New techniques for estimating supplement intake by grazing herbivores. In Emerging Techniques for Studying the Nutritional Status of Free-ranging Herbivores [H Dove and SW Coleman, editors]. Satellite Meeting of the Vth International Symposium on the Nutrition of Herbivores, San Antonio, Texas (CD-ROM).

Malossini F, Bovolenta S, Piasentier E, Piras C \& Martillotti F (1996) Comparison of $n$-alkanes and chromium oxide methods for estimating herbage intake by grazing dairy cows. Animal Feed Science and Technology 61, 155-165.

Martin AK, Milne JA \& Moberly P (1983) The origin of urinary aromatic compounds excreted by ruminants. 4. The potential use of urine aromatic acid and phenol outputs as a measure of voluntary food intake. British Journal of Nutrition 49, 87-99.

Martz FA, Belo AT, Weiss MF \& Belyea RL (1999) True absorption of calcium and phosphorus from corn silage fed to nonlactating, pregnant dairy cows. Journal of Dairy Science 82, 618-622.

Matsumoto H \& Sugawara K (1997) Use of opal phytoliths as a marker for the identification of plant species and herbage intake ingested by grazing animals. 1. Identification of plant species by opal phytoliths and changes in opal phytolith composition at growth stages. Grassland Science 43, 249-257.

Mayes RW, Beresford NA, Howard BJ, Vandecasteele CM \& Stakelum G (1996) Use of the true absorption coefficient as a measure of bioavailability of radiocaesium in ruminants. Radiation and Environmental Biophysics 35, $101-109$.

Mayes RW, Beresford NA, Lamb CS, Barnett CL, Howard BJ, Jones B-EV, Eriksson O, Hove K, Pedersen Ø \& Staines BW (1994) Novel approaches to the estimation of intake and bioavailability of radiocaesium in ruminants grazing forested areas. Science of the Total Environment 157, 289-300.

Mayes RW, Dove H, Chen XB \& Guada JA (1995) Advances in the use of faecal and urinary markers for measuring diet composition, herbage intake and nutrient utilisation in herbivores. In Recent Developments in the Nutrition of Herbivores, pp. 381-406 [M Journet, E Grenet, M-H Farce and C Demarquilly, editors]. Paris: INRA Editions.

Mayes RW, Dove H, Lamb CS \& Ellis KJ (1991) Evaluation of an intraruminal device for the controlled release of an alkane marker for intake estimation in sheep. In Proceedings of the 42nd Annual Meeting of the European Association of Animal Production, Vol. 1, pp. 456-457.

Mayes RW \& Duncan AJ (1999) New developments in the use of plant-wax markers to determine intake. In Emerging Techniques for Studying the Nutritional Status of Free-ranging Herbivores [H Dove and SW Coleman, editors]. Satellite Meeting of the Vth International Symposium on the Nutrition of Herbivores, San Antonio, Texas (CD-ROM).

Mayes RW \& Lamb CS (1984) The possible use of $n$-alkanes in herbage as indigestible faecal markers. Proceedings of the Nutrition Society 43, 39A.

Mayes RW, Lamb CS \& Colgrove PM (1986a) The use of dosed and herbage $n$-alkanes as markers for the determination of herbage intake. Journal of Agricultural Science 107, 161-170.

Mayes RW, Lamb CS \& Colgrove PM (1988) Digestion and metabolism of dosed even-chain and herbage odd-chain $n$ alkanes in sheep. Proceedings of the XIIth General Meeting of the European Grassland Federation, pp. $159-163$.

Mayes RW, Wright IA, Lamb CS \& McBean A (1986b) The use of long-chain $n$-alkanes as markers for estimating intake and digestibility of herbage in cattle. Animal Production 42, 457.

Mayland HF, Florence AR, Rosenau RC, Lazar VA \& Turner HA (1975) Soil ingestion by cattle on semi-arid range as reflected by titanium analysis of feces. Journal of Range Management 28, 448-452.

Miraglia N \& Tisserand JL (1985) An enzymatic procedure for estimating horse forage digestibility. Annales de Zootechnie 34, 229-236.

Moen R \& DelGuidice GD (1997) Simulating nitrogen metabolism and urinary urea nitrogen:creatinine ratios in ruminants. Journal of Wildlife Management 61, 881-894.

Mohammad AG, Pieper RD, Wallace JD, Holechek JL \& Murray LW (1995) Comparison of fecal analysis and rumen evacuation techniques for sampling diet botanical composition of grazing cattle. Journal of Range Management $\mathbf{4 8 ,}$ $202-205$

Molle G, Decandia M \& Dove H (1998) A comparison between different procedures for dosing $n$-alkanes to sheep. Proceedings of the IXth European Intake Workshop, pp. 53-57, North Wyke, Devon, UK. 
Moughan PJ (1999) In vitro techniques for the assessment of the nutritive value of feed grains for pigs: a review. Australian Journal of Agricultural Research 50, 871-879.

Moughan PJ, Smith WC, Schrama J \& Smits C (1991) Chromic oxide and acid-insoluble ash as faecal markers in digestibility studies with young growing pigs. New Zealand Journal of Agricultural Research 34, 85-88.

Nagy KA, Girard IA \& Brown TK (1999) Energetics of free-ranging mammals, reptiles, and birds. Annual Review of Nutrition 19, 247-277.

Newman JA, Thompson WA, Penning PD \& Mayes RW (1995) Least-squares estimation of diet composition from $n$ alkanes in herbage and faeces using matrix mathematics. Australian Journal of Agricultural Research 46, $793-805$.

O'Keefe NM \& McMeniman NP (1998) The recovery of natural and dosed $n$-alkanes from the horse. Animal Production in Australia 22, 337.

Orr A (1998) The intake of herbage, supplementary feed and performance of growing ostriches (Struthio camelus), given two different feeding regimens, in North East Scotland. MSc Thesis, University of Aberdeen.

Pagella JH (1998) Urinary benzylated compounds as potential markers of forage intake and metabolism of their precursors in ruminants. PhD Thesis, University of Aberdeen.

Pastor J, Dewey B, Naiman RJ, McInnes PF \& Cohen Y (1993) Moose browsing and soil fertility in the boreal forests of Isle-Royale National Park. Ecology 74, 467-480.

Penning PD (1983) A technique to record automatically some aspects of grazing and ruminating behaviour in sheep. Grass and Forage Science 38, 89-96.

Penning PD \& Hooper GE (1985) An evaluation of the use of short-term weight changes in grazing sheep for estimating herbage intake. Grass and Forage Science 40, 79-84.

Penning PD \& Johnson RH (1983a) The use of internal markers to estimate herbage digestibility and intake 1. Potentially indigestible cellulose and acid insoluble ash. Journal of Agricultural Science 100, 127-132.

Penning PD \& Johnson RH (1983b) The use of internal markers to estimate herbage digestibility and intake 2. Indigestible acid detergent fibre. Journal of Agricultural Science 100, 133-138.

Piasentier E, Bovolenta S, Malossini F \& Susmel P (1995) Comparison of $n$-alkanes or chromium-oxide methods for estimation of herbage intake by sheep. Small Ruminant Research 18, 27-32.

Provenza FD, Villalba JJ, Cheney CD \& Werner SJ (1998) Self-organization of foraging behaviour: From simplicity to complexity without goals. Nutrition Research Reviews 11, 199-222.

Raats JG, Webber L, Tainton NM \& Pepe D (1996) An evaluation of the equipment for the oesophageal fistula valve technique. Small Ruminant Research 21, 213-216.

Reeves M, Fulkerson WJ, Kellaway RC \& Dove H (1996) A comparison of three techniques to determine the herbage intake of dairy cows grazing kikuyu (Pennisetum clandestinum) pasture. Australian Journal of Experimental Agriculture 36, 23-30.

Rogers JA, Odwongo WO \& Conrad HR (1985) Estimation of forage dry-matter intake in lactating dairy cows using a deuterium oxide dilution technique. Journal of Dairy Science 68, 2596-2601.

Rutter SM (1999) Developments in the use of microcomputer-based methods for the automatic recording of grazing behaviour. In Emerging Techniques for Studying the Nutritional Status of Free-ranging Herbivores [H Dove and SW Coleman, editors]. Satellite Meeting of the Vth International Symposium on the Nutrition of Herbivores, San Antonio, Texas (CD-ROM).

Salt CA, Mayes RW, Colgrove PM \& Lamb CS (1994) The effects of season and diet composition on the radiocaesium intake by sheep grazing on heather moorland. Journal of Applied Ecology 31, 125-136.

Salt CA, Mayes RW \& Elston DA (1992) Effects of season, grazing intensity and diet composition on the radiocaesium intake by sheep on re-seeded hill pasture. Journal of Applied Ecology 29, 378-387.

Samaniego MA (1996) Comparison of methods for the measurement of digesta flow and microbial protein supply in sheep. MSc Thesis, University of Aberdeen.

Saul GR, Flinn PC \& Heard JF (1986) The nutritive value of roughages before and after mastication by oesophageally fistulated sheep. Proceedings of the Australian Society of Animal Production 16, 351-354.

Sendalo DS (1995) Tethering of goats in Tanzania: purpose, and implications with special reference to effects on grazing behaviour and intake. PhD Thesis, University of Reading.

Silanikove N, Holzer Z, Cohen D, Benjamin R, Gutman M \& Meltzer A (1987) Interrelationship between metabolism of tritiated water, ${ }^{22}$ sodium and dry matter intake by beef cattle consuming wheat straw and poultry litter in free choice. Comparative Biochemistry and Physiology A 88, 113-118.

Smith LW (1989) A review of the use of intrinsically ${ }^{14} \mathrm{C}$ and rare earth-labeled neutral detergent fiber to estimate particle digestion and passage. Journal of Animal Science 67, 2123-2128.

Staaland H, Holleman DF, Luick JR \& White RG (1982) Exchangeable sodium pool size and turnover in relation to diet in reindeer. Canadian Journal of Zoology 60, 603-610.

Suharyono, Nolan JV \& Kent J (1991) Estimation of supplement intake in individual grazing ruminants using lithium chloride as a marker. In Recent Advances in Animal Nutrition in Australia, p. 16A [DJ Farrell, editor]. Armidale: University of New England.

Tieszen LL, Boutton TW, Tesdahl KG \& Slade NA (1983) Fractionation and turnover of stable carbon isotopes in animal tissue: Implications for $\delta^{13} \mathrm{C}$ analysis of diet. Oecologia 57, 32-37.

Tilley JMA \& Terry RA (1963) A two-stage technique for the in vitro digestion of forage crops. Journal of the British Grassland Society 18, 104-111. 
Todd LK, Sauer WC, Christopherson RJ, Coleman RJ \& Caine WR (1995) The effect of feed-intake on nutrient and energy digestibilities and rate of feed passage in horses. Journal of Animal Physiology and Animal NutritionZeitschrift für Tierphysiologie Tierernahrung und Futtermittelkunde 73, 140-148.

Udén P, Colucci PE \& Van Soest PJ (1980) Investigation of chromium, cerium and cobalt as markers in digesta rate of passage studies. Journal of the Science of Food and Agriculture 31, 625-632.

Vagnoni DB, Garrott RA, Cook JG, White PJ \& Clayton MK (1996) Urinary allantoin : creatinine ratios as a dietary index for elk. Journal of Wildlife Management 60, 728-734.

Vivås HJ \& Sæther B-E (1987) Interactions between a generalist herbivore, the moose, Alces alces, and its food resources: an experimental study of winter foraging behaviour in relation to browse availability. Journal of Animal Ecology 56, 509-520.

Walker JW, Clark DH \& McCoy SD (1998) Fecal NIRS for predicting percent leafy spurge in diets. Journal of Range Management 51, 450-455.

Wallace-Drees JM, Immink HJ, Bruyn G-J \& Slim PA (1986) The use of fragment-identification to demonstrate shortterm changes in the diet of rabbits. Acta Theriologica 31, 293-301.

Wamberg S, Elnif J \& Tauson AH (1996) Assessment of the accuracy of quantitative urine collection in mink (Mustela vison) using osmotic pumps for continous release of $p$-amino-hippuric acid and inulin. Laboratory Animals 30, 267272.

Webber MD, Piezt RI, Granato TC \& Svoboda ML (1994) Plant uptake of PCBs and other organic contaminants from sludge-treated coal refuse. Journal of Environmental Quality 23, 1019-1026.

Wilson H (1998) An evaluation of $n$-alkanes as a method of measuring herbage intake in sows. MSc Thesis, University of Aberdeen.

Wilson H, Sinclair AG, Hovell FDeB, Mayes RW \& Edwards SA (1999) Validation of the $n$-alkane techniques for measuring herbage intake in sows. Proceedings of the British Society of Animal Science 171.

Woolnough AP (1998) The feeding ecology of the northern hairy-nosed wombat, Lasiorhinus krefftii (Marsupialia: Vombatidae). PhD Thesis, Australian National University. 